\title{
Democratization and Civic Capital
}

\author{
Luigi Guiso \\ European University Institute, EIEF, \& CEPR \\ Paolo Pinotti \\ Bocconi University \& DONDENA
}

September 2011

\begin{abstract}
We document a sharp reversal in electoral participation between the North and the South of Italy after the 1912 enfranchisement which extended voting rights from a limited élite to (almost) all adult males. When voting was restricted to the élite, electoral turnout was higher in the South but falls significantly below that in the North after the enfranchisement. Furthermore the new gap is never bridged over the following century and participation remains lower in the South despite the enrichment of democratic institutions and further extension of voting rights to the female population during the post war democratic republic. This pattern in the data is consistent with a simple model where individuals' voting in political elections is affected by private benefits and by civic duty, only elites can grab private benefits from participation in politics and civic culture differs across communities. We also find that extension of voting rights to non-elites results in a significant transfer of power to their political organizations only among populations with a high sense of civic duties. Together with the very persistent gap in participation between North and South our findings suggest that democratization - a process of concession of democratic rights can benefit non-elites only when the latter have already a high sense of civic capital and is unlikely to be a viable avenue for inducing norms of civic behavior.
\end{abstract}

Keywords: Democracy, culture, civic capital, institutions formation JEL: 


\footnotetext{
"If the democratic model of the participatory state is to develop in these new nations it will require more than the formal institutions of democracy - universal suffrage, the political party, the elective legislature. These in fact are also part of the totalitarian participation pattern, in a formal if not functional sense. A democratic form of participatory political system requires as well a political culture consistent with it."

Gabriel Abraham Almond and Sidney Verba, "The Civic Culture: Political Attitudes and Democracy in Five Nations"
}

\section{Introduction}

In an attempt to explain why differences in economic success across countries tend to persist over the course of centuries, during the past decade a new literature has drawn attention to the role of institutions in affecting economic performance and its persistence. One strand of literature led by the work of Acemoglu et al. (2001, 2005), has focused on the role of formal institutions. Protection of property rights and limitations on the power of the executive, which - they claim are essential to the development process, are built into the formal institution of a county and tend to persist over the centuries. A parallel strand, linked to La Porta et al. (1998), has emphasized the importance of legal traditions and the beneficial effects of British legal origin for the development of financial markets and ultimately for economic development. Dismantling dysfunctional formal institutions and replacing them with more economy-friendly ones, such as institutions and political processes that constrain the power of the executive, may be seen as a recipe for economic development. One important issue is then what makes an institutional reform successful.

A second strand of literature has called attention to the role of informal institutions, in particular the prevalence of cultural values of cooperative behavior and beliefs of mutual trust (Tabellini (2008b), Guiso et al. (2004, 2008c), Knack and Keefer (1997)) as well as values of fairness and individualism that instill a sense of self confidence in economic actors (Roland and Gorodnichenko, 2011a, 2011b) promoting achievement and innovation, in the tradition of Max Weber. Though it has been often been recognized that there could be complementarities and mutual influences between informal cultural norms and formal institutions (e.g. Tabellini 
(2008b)), these two strands have mostly moved in parallel. Yet, because cultural norms in general evolve slowly, more slowly than formal political or legal institutions (Williamson, 2000), they may act as a constraint (Roland, 2004) and may affect the success of institutional reform and ultimately the type of institutions that actually prevail in a country. This was indeed the pathbreaking contribution of Robert Putnam (1993) - showing that the performance of (formal) regional governments instituted in Italy in 1970 depended on the (informal) set of values and beliefs, i.e. the civic traditions, prevailing in each region. More recently, Murrel and Smith (2011) argue that the important institutional change brought about by the Glorious Revolution of 1688 was made possible by the cultural changes that preceded formal institutional reforms.

In this paper we study how pre-existing cultural norms of civic behavior interact and affect the success of a major institutional reform - a democratization reform through the extension of voting rights from a restricted elite to a vast segment of the population. We draw data from the Italian 1912 enfranchisement which granted voting rights, once restricted to a minority based on income, to almost all adult males. We document that when voting was restricted to the élite participation in political elections was significantly and consistently higher in the Southern regions of the country, those that according to Putnam (1993) and, more recently, Guiso et al. (2004, 2010a, 2010b) are less endowed with civic capital. This feature itself may sound puzzling precisely because electoral turnout itself has been used to document the prevalence of norms of cooperation and civic engagement in the North of Italy. After the enfranchisement participation drops both in the North and in the South but much more in the latter than in the former so that there is a reversal.

We argue that the pattern in the data is consistent with a simple model where voting in political elections is driven both by a private rent-seeking motive because political power can give rise to private benefits and by the diffusion of cultural norms of civic engagement that regard voting as a duty. Both motives are however heterogeneous within the population: access to political power and thus to private benefits is stronger for élites, for instance because its members are better at pooling together the resources necessary to run for office; the importance of norms of civic participation differs across communities, strong in the North and weak in the South in obedience to the different civic traditions of the country initially documented by Putnam (1993), Banfield 
(1958) and, more recently, Guiso et al. (2010a). The model yields three predictions: first, participation in political elections is higher among élites because, ceteris paribus, they have both a social and a private motive for voting; second, the difference in participation between élite and non-élite voters decreases as the level of civicness increases because higher civicness strengthens the motive to participate of both élite and non-élite voters. Finally, these two results jointly imply that the enfranchisement of non-elites decreases voting turnout, the more so in less civic regions. The latter implication can easily rationalize the reversal in turnout between the North and the South of Italy following the franchise provided the difference in civic culture and/or in the relative size of elites vs. non-elites groups between the two areas is large enough.

When we test these implications in our data we indeed find that electoral participation increases with social status and the relationship is steeper in communities with weaker civic culture. This is true both across individuals in social survey data from around year 2000 and across regions and electoral districts during the period between the Italian Unification and the advent of the Fascism (1861-1921). Most interestingly, the effect of the 1912 enfranchisement was to lower electoral turnout across the board but much more so in the low civicness regions: the drop is estimated to be between 14 and 20 percentage points larger in the Sorthern regions than in those in the North, and this effect is strong enough to reverse the higher political participation among the élites in the South. This result is not due to differences in civic capital reflecting differences in literacy or in economic development between Northern and Southern regions at time of enfranchisement, as it persists when we control for these factors. We also control for the relative size of the newly enfranchised non-elites, i.e. the "treatment intensity" of enfranchisement, as approximated by the change in the electorate between the last pre-enfranchisement and the first post-enfranchisement election. Indeed, differences along this dimension allow for a definitive empirical test of the model across electoral district within the same area. Consistently with our theoretical hypotheses, we find that voting turnout decreases with the size of non-elite groups both in Northern and Southern regions, but the slope is steeper in the latter relative to the former.

Taken together this evidence is consistent with the view, first explored in the seminal and influential work of Almond and Verba (1963), that democratization to be effective requires that non-élites are ready and willing to exercise their voting rights when reforms grant them voting 
power: but this willingness and readiness depends in turns on whether a culture of civicness is already diffuse. To inquire this issue more directly we study how non-élites voted once they were granted democratic rights. Arguably, a democratization reform is successful if non-élites make an extensive use of these rights and if their votes are not captured by pre-existing élites but are used to strengthen their representativeness. That is, the reform is successful if it generates a substantial reallocation of political power away from élites. We find that following the enfranchisement, radical socialist and communist parties whose manifestos better reflected nonélites interests gained a significant consensus only in the civicness-rich Northern regions, where these parties reached almost $50 \%$ of total votes in the last elections before the fascism. Thus lack of civic culture threatens the success of democratization reforms both because fewer members of non-élites choose to use their voting power and because those who do so are strongly influenced by previous élites in their choices. ${ }^{1}$ These findings add to parallel work by Larcinese (2011), who also investigates the effects of the 1912 enfranchisement on the electoral success of radical parties; later in this paper we will compare closely his and our findings.

Overall, these results show that "de jure" concession of political rights taking place with the enfranchisement resulted at the time into a "de facto" re-allocation of political power only in the regions were the non-elites were willing to actually exert those rights. Did this difference disappeared over time as people voted repeatedly and possibly learned how to benefit from extended democratic rights? Did the formal democratic rights contributed to develop what in the Almond and Verba's original study are the values and attitudes that sustain democratic institutions and which relate to the manner in which people within a polity view their relationships with others vis a vis their own interests? Put differently, did the 1912 enfranchisement and the subsequent extension of voting rights to the whole population independently of gender after WWII bridge the gap in people civicness across regions of the

\footnotetext{
${ }^{1}$ This pattern of behaviour is consistent and probably has contributed to shape Mosca (1939) sceptical view about the working of democracies where in any case a minority - the élite - ends up exercising the political power and controlling the majority thanks to its their greater organizational skills compared to non-elites. Lack of civic culture and thus of an understanding of the power of voting among non-élites can be seen as limited possession of "organizational skill".
} 
country? A simple comparison of participation in political elections after WWII reveals a persistent gap between north and south, suggesting that democratization did not bridge the gap. We further address comparing data on political elections and referenda turnout in referenda and political elections that took place after WWII. Since participation in political election may have also a private returns one should expect that it is higher in elections than in referenda, where voting carries no private benefits. However, if the civicness gap has been bridged we should find that this difference is the same between the North and the South of the country; on the other hand it still persists after decades of democratic rights the difference should be larger in the South than in the North. This is what the data suggest.

The rest of the paper is organized as follows. In Section 2 we describe the historical background and present descriptive data about participation before and at time of enfranchisement, particularly the dramatic reversal in voting turnout between Northern and Southern electoral districts. Section 3 presents a streamlined model of voting decision and obtains predictions that are then confronted with the data in Sections 4 and 5. Section 6 concludes.

\section{Historical background}

\subsection{Pre-Unitarian institutions and civic traditions in Italy}

The unification of Italy in 1861 is the end of a long process of political disintegration into a large number of local powers and subsequent consolidation that started around the turns of the first millennium. This process was triggered by the collapse of the Carolingian Holy Roman Empire under which today Italy's borders where unified. As the central power of the Empire fell a number of local powers emerged in order to fill in the vacuum. But the way this lack of power was filled in differs between the North and the South of Italy, and this difference is presumably at the origin of different civic traditions. Due to a number of historical contingences (the greater distance from the headquarters of the Emperor, the relative weak army of the Papal state) the South of Italy went conquered by the Normans which replaced the authority of the Emperor and established a highly hierarchical system of government that persisted, under different rulings, 
until Italy unifications for about 700 years. The North instead saw the affirmation of selfgovernment in cities, a feature that spread over Northern Central and Western Europe (Reynolds, 1997; McKitterick, 2004) but whose development was particularly strong in NorthernCentral Italy between 1100 and 1300. Initially, in response to this vacuum of power and in order to manage the problems of common interest that the absenteeism of the Emperor was giving rise to (such as the maintenance of the city walls, the security of trade routes etc.), small groups of individuals in some cities joined forces and formed a "pact" to provide mutual help and collaboration to solve problems of common interest. In some cities (such as Genoa) this alliance involved the prominent families of the marine aristocracy who swore to work together to manage the city. From this seed, slowly more stable institutions started to develop. Initially was the creation of the consulate - a group of citizens that hold power for a year and were then replaced by another group, allowing a vast share of the populations to take charge of local government and acquire familiarity with political engagement. According to Milani the counsels for the administration of the city marks the most visible sign of the rise of the free city as an independent political body (Milani, 2005, p. 23). Over the course of the centuries these initial institutions evolved into a formal "parliament" of elected members that allowed for a wider participation of the population in the decision making process. With these changes, the independent city-state was fully developed. It provided law and order, collected duties and tolls, took care of the walls that provided the basic protection to the citizens and was responsible for the maintenance and security of the roads, essential to guarantee trade, which was developing fast. In the mid-twelfth century a new word came into use to describe the independent town communities and their government: “commune”. As Reynolds (1997) notices “... its use in urban context may derive from communia, meaning common property: not only walls and streets but also cathedrals and churches were increasingly regarded as the responsibility and therefore the property of the local community. Their rights and liberties were also their common property which it was their responsibility to maintain (p. 170)". Indeed, the word commune is a synonym for republic (res publica, i.e. common property) and is used with this meaning. This sense of responsibility for the common good that citizens of independent towns developed and consolidated over two centuries of self-government is the "civicness" Putnam refers to which seems to characterize the 
North of the country and which was missing in the South because the hierarchical system of government suppressed any involvement of its populations with the management of power and the responsibility of government.

Guiso et al. (2010) who provide a fuller account of the evolution of the free cities highlight three features of the free system of cities that has contributed to shaping its citizens political culture. First, the fact that the political entity was not identified with a single person ruling but rather with the whole community. Second, the ruler ruled in people name - that is the citizens were the source of power and thus its exercise required people consensus, though obviously prominent families mattered a lot. Third, the commune has a statute - similar to a constitution - enacted by an assembly and norms apply to the whole population independently of status, as it was in feudal times. In sum, the commune grants legal protection to personal freedoms and thus limits the power of the executive, a feature that as argue by Acemoglu and Johnson (2005) is necessary for development.

Finally, all these democratic characteristics of the free city and its emergence were not the result of unilateral concessions from the Emperors but rather a need for their citizens to provide local government services when the central authority of the Empire stopped to function. We will come back to this point in the conclusions.

The system of free cities evolved over time as cities fought against each other and the losers were conquered by the winners; with time, the elected bodies were slowly replaced by more centralized forms of government which evolved into the Signoria - the power of the lord. However, even these centralized powers retained many traits of the free cities, in particular the principle that power originated from people and was exercised in people's name.

When the process of unification started around the Vienna congress in 1815 Italy was a politically divided country with many kingdoms but with an even bigger culture divide - that between the South, at the time dominated by the Bourbons, and the North, where the civic culture created with free cities prevailed. In the South citizens were probably well characterized by what Almond and Verba defined "parochial" - politically sleepwalker, not involved, with little or no 
knowledge or interest in the domestic political system; in the North they were probably much closer to the "participant" type - people possessing a strong sense of influence, competence and confidence in understanding domestic political matters.

Indeed, such differences were to be found in the civic capital endowments accumulated many years later, after the unification of the country. While in general information on civic traditions during the past centuries is not readily available, the Ministry of Agriculture, Industry and Commerce (1888) published regional statistics on the diffusion of voluntarily mutual aid societies and cooperatives, which is one of the main indicators of civic capital considered by Putnam (1993). ${ }^{2}$ The picture in Figure 1, plotting the distribution of such organizations over total population across Italian regions, is consistent with the persistence of a huge cultural divide between north and south even decades after the unification of the country.

\subsection{From the Unification to the enfranchisement of 1912}

The political fragmentation of the Italian peninsula finally came to an end during the second half of the $19^{\text {th }}$ century with the so-called Risorgimento (the "resurgence"). The nationalistic sentiments once confined to the narrow circle of intellectual elites spread out in the aftermath of the Congress of Vienna, which imposed the dominion of the Habsburgs over most of Northern Italy, while the Centre and South were still controlled by the Church State and the Bourbons, respectively. Following a number of crushed insurrections during the period between the 1820s and the European Revolutions of 1848, the strategic alliance with Napoleon III allowed the Kingdom of Sardinia (actually centered around the Savoy Monarchy in Piedmont) to overcome Austria in 1859, while the Bourbons were defeated with the expedition of Garibaldi in 1860. After the proclamation of the Kingdom of Italy in 1861, another war against Austria for the northeastern regions (1866) and the annexation of the remaining territories of the Church State (1870) completed the re-unification of the country.

\footnotetext{
${ }^{2}$ Mutual aid societies were formed among urban artisans and craftsmen as an insurance device against accidents and economic hardship; similarly, cooperatives provided mutual assistance to their members, being them workers, producers or consumers. As argued by Putnam (1993), "mutual aid societies provided a locally organized, underfunded, self-help version of what the twentieth century would call the welfare state (...) represented collective solidarity in the face of the economic insecurities peculiar to the modern age".
} 
Throughout all these events (maybe with the exception of the Garibaldi expedition), the Risorgimento remained essentially an affair between the Savoy Monarchy and the urban high class, while large segments of the peasant population were at best skeptical (or even fiercely against) the process of unification. This influenced deeply the institutional architecture of the newborn Kingdom of Italy, which among other things restricted the suffrage in the elections for the National Parliament to wealthy adult males paying more than 40 Italian liras of taxes - about 420 thousand individuals in 1861, or $1.9 \%$ of total population. In 1876 the income threshold was lowered from 40 to 19.80 liras (and the minimum age from 25 to 21), but it was not until 1912 that the census criterion was finally abolished, at least for all individuals above 30; even for those aged between 21 and 30, compliance with compulsory military service became a sufficient condition for voting, extending the suffrage to almost 8.7 millions of individuals - about the entire adult male population.

Interestingly, the enfranchisement of $1912 \mathrm{did}$ not represent a political achievement of the left; rather, it was a concession of the liberal coalition led by Giolitti. While its political motivations are subject to considerable speculation among historians, the reform was probably aimed at undermining the strength of the revolutionary movement amid increasing social unrest during the first decades of the XX century, consistently with the idea of Acemoglu and Robinson (2000) that the risk of a violent revolution may trigger political reforms.

Whatever the reason for such concession, Figure 2 shows that the enfranchisement had immediate effects on electoral participation in Italy:

i. participation declined everywhere right after the enfranchisement;

ii. the drop was significantly larger in southern than in northern regions, leading to a reversal in voting turnout between the two areas before and after 1912.

Importantly, the differential accumulated in the first decades of the XX century is not dissipated during the following one hundred years, characterized instead by a continuous divergence between northern and southern regions. 
In the next section we sketch a simple theoretical framework that provides an explanation for these patterns. By focusing on the differential dynamics between north and south we will instead neglect the long-run increase in voting turnout that characterizes both areas, which likely reflects a continuous process of accumulation of human capital as well as other aspects of economic development.

\section{Theoretical framework}

Consider two types of individuals, the elite and the non-elite, that must decide whether or not to participate in politics (voting). The benefits of participation depend on two elements: the extraction of private rents and the social value associated with political participation.

Private rents might include the returns to connection with politicians, favors obtained from supporting a candidate, the possibility of exercising political control and thus diverting resources in a desired direction, or the labor market premium enjoyed by former politicians, for instance because of their subsequent involvement in lobbying (see e.g. Fisman, 2001, Diermer et al., 2005, Ferguson and Voth, 2008, and Acemoglu et al. 2010). We assume that access to such rents increases with membership in elite groups; for example, belonging to the same restricted club may facilitate connections between appointed politicians and entrepreneurs. This is indeed the picture that emerges from the historical "portrait" of the American elites that is depicted by Mills (1945).

Apart from private gains, political participation may be also motivated by a genuine desire to contribute to the functioning of the political system - what we call "civicness". For instance, voting in elections allows for an ordered succession of powers in democratic systems: while in large elections the probability that each single voter is pivotal tends to zero, nevertheless the individual decision to vote contributes to the existence of an electoral result, in the same way as the participation of infinitesimal agents contribute to the existence of many other public goods. We assume that the relative importance of private and social motives for participating in politics depends on the individual degree of civicness. Specifically, the utility of participating equals

$$
U(\alpha)=\alpha S+(1-\alpha) R-c
$$


where $\alpha$ is an index of civicness ranging between 0 and $1, S$ is the social value of participation in politics (the utility from exercising the duty of voting) and $R$ are the private rents that descend from it; we assume $R=0$ for the non-elites. ${ }^{3}$ Finally, the last term in (1) is the private cost of participating in politics, which may range from the "shoe-leather cost" of voting to the time and effort devoted to electoral campaigning. We assume that $c$ is heterogeneously distributed across the population of agents according to the cumulative distribution $F(c)$.

Each individual participates in politics if and only if the benefits of doing so outweigh the cost, i.e.

$$
U(\alpha) \geq 0 \Leftrightarrow c \leq \alpha S+(1-\alpha) R
$$

Therefore, the share of participants among the elites $(E)$ and the non-elites $(N)$ equals, respectively, $\pi_{E}(\alpha)=F(\alpha S+(1-\alpha) R)$ and $\pi_{N}(\alpha)=F(\alpha S)$ so that the difference between the two groups is

$$
\Delta \pi(\alpha)=\pi_{E}(\alpha)-\pi_{N}(\alpha)
$$

This simple model delivers three key results. From the fact that $F($.$) is monotonically increasing, it$ follows immediately that:

R1. On average, political participation is always higher among the elites than the non-elites,

$$
\Delta \pi(\alpha) \geq 0 \text {, with } \Delta \pi(\alpha)>0 \text { for any } \alpha<1 \text {, }
$$

as the elites enjoy additional rents from political participation relative to the non-elites;

R2. The difference in participation between the two groups decreases with civicness,

$$
\Delta \pi\left(\alpha^{\prime}\right)<\Delta \pi(\alpha) \text { for any } \alpha^{\prime}>\alpha
$$

intuitively, more (less) civic elites attach less (more) importance to private rents relative to the social value of political participation.

\footnotetext{
${ }^{3}$ This stark assumption can be relaxed by letting $R$ increase monotonically with some continuous index of social status.
} 
Finally, results R1 and R2 have immediate implications for the consequences of the enfranchisement of the non-elites:

R3. The enfranchisement of non-elites decreases voting turnout, the more so in less civic regions.

Indeed, voting turnout $V$ equals the voting participation of elites and non-elites weighted by the relative size of the two groups,

$$
V=n \pi_{N}(\alpha)+(1-n) \pi_{E}(\alpha)=\pi_{E}(\alpha)-\Delta \pi(\alpha) n
$$

where $n$ is the share of non-elite agents in the electorate. As the latter increases from zero to some positive value after the enfranchisement, it follows directly from R1 that voting turnout must decrease; moreover, R2 implies that the drop should be larger in less civic regions. A corollary is that two areas can exhibit a reversal in voting turnout like that observed in Figure 2, provided that they differ enough in terms of culture and/or composition of the electorate. Specifically, for any two regions characterized by different levels of civicness and shares of non-elite voters, the reversal in sign before and after the enfranchisement requires that

$$
\pi_{E}\left(\alpha^{\prime}\right)-\pi_{E}(\alpha)<0<\left[n^{\prime} \pi_{N}\left(\alpha^{\prime}\right)+\left(1-n^{\prime}\right) \pi_{E}\left(\alpha^{\prime}\right)\right]-\left[n \pi_{N}(\alpha)+(1-n) \pi_{E}(\alpha)\right]
$$

or $n^{\prime} \Delta \pi\left(\alpha^{\prime}\right)-n \Delta \pi(\alpha)<0$. A sufficient condition for the latter inequality to hold is that $\alpha^{\prime}-\alpha>0$ and $n^{\prime}-n<0$. We argued in the previous section that past institutional history favored a greater accumulation of civic capital in northern than in southern Italian regions; moreover, we will show in Section 5 that after the enfranchisement the share of non-elite voters in the electorate was smaller in the former than in the latter. Therefore, the predictions of this simple theoretical framework are consistent with the reversal in voting turnout between the two areas.

Before moving to a throughout empirical analysis of the relationship between civicness, electorate's composition and enfranchisement, we test confront the theoretical model (particularly predictions R1 and R2) with the individual-level evidence emerging from social survey data around year 2000. 


\section{Individual-level evidence}

Bringing the model to the data, we expect from equation (3) a positive relationship between socio-economic status and political participation; moreover, the result in equation (4) implies that the slope of such relationship should be steeper in less civic regions. This is exactly the picture that emerges from Figure 3, which plots average voting turnout and direct involvement in politics by socio-economic status and region of residence for a sample of Italian individuals interviewed during the fourth wave of the World Values Survey (WVS).

The WVS is a large survey program providing comparable evidence across countries about individual values, beliefs and attitudes along several dimensions, including politics. In particular, two questions in the survey asked, respectively, whether the respondent intended to vote in the following elections and whether (s)he was directly involved in politics, in the sense of being an appointed politician or government official or, at least, working for some party. While the question was asked in all editions of the survey, only in the fourth wave (years 1999-2004) the respondent could explicitly choose not to vote for any party. ${ }^{4}$ Finally, the WVS does also provide a 4-value index of individual socio-economic status.

The graphs in Figure 3 convey two main results. First, political participation increases with socioeconomic status, in line with prediction R1 of the theoretical model. Second, the differential between elites and non-elites is greater in Southern than in Northern regions. As long as civicness is lower in the former relative to the latter (as extensively documented by the literature discussed in Section 2.1), the difference in slopes is consistent with prediction R2 of the model. ${ }^{5}$

To quantify these findings, we regress each of the two measures of political participation on dummies for socio-economic status (individuals in the lowest class are the excluded category), distinguishing between northern and southern regions. Table 1 presents the results for voting in national elections. In line with the graphical evidence in Figure 3, the regression in column (1)

\footnotetext{
${ }^{4}$ The WVS is currently in its fifth wave and results are fully available for the first four waves. In the first three waves the choice not to vote was lumped together with voting for other parties not listed in the questionnaire and/or missing values.

${ }^{5}$ Following Guiso et al. (2010), we excluded from the sample the island of Sardinia as its civic traditions are rather peculiar relative to any of the two groups.
} 
shows that the probability of voting increases monotonically with socio-economic status, up to an additional 11 percentage points (one-third of the sample standard deviation) for people in the top social status group. The estimated difference is lower after controlling for region fixed effects and for a wide array of individual characteristics (column 2); however it remains sizeable (about 7 percentage points) for individuals highest in status. ${ }^{6}$ In column (3) and (4) we estimate the same relationship separately for individuals residing in different areas of Italy. The estimates suggest that the slope is much steeper in southern regions, where electoral participation is 20 percentage points higher for individuals at the top of social status (as opposed to no significant effect in northern regions). The difference-in-differences specification in column (5) confirms that the differential increase is statistically significant only for individuals in the top class, consistent with the idea that private rents from political activity matter mostly for the elites.

In Table 2 we estimate the same linear probability model for active participation in politics, either through membership in some party or direct appointment in office. While this is possibly a more interesting outcome than the simple act of voting in elections, direct involvement in politics is also an extremely rare event, so that the numbers in small samples can be quite noisy; specifically, out of 1,368 individuals in our sample, 74 were members of some party, 43 actively worked for the party and only 6 were appointed in some political body. With these caveats in mind, the results are qualitatively very similar to those obtained for voting behavior, namely that political participation increases significantly with socio-economic status only in southern regions, particularly so for the members of the elite.

Overall, the results in this section largely support our theoretical framework. For this reason, in the next section we adopt the same model to study the effects of the enfranchisement of non-elite voters in Italy.

\footnotetext{
${ }^{6}$ Individual controls include socio-demographic characteristics (age, age squared, gender and indicator variables for number of children and size of the town of residence) and other determinants of voting behavior, namely beliefs in democracy. Specifically, three questions in the WVS ask, respectively, whether the individual agrees or not (on a 4-value scale) with the fact that "democracy may have problems but is better than any other form of government"; "in democracy the economic system runs badly"; it is better "having the army rule".
} 


\section{Historical evidence}

The preliminary evidence presented in Section 2.2 documents stark changes in voting patterns across Italian regions before and after the enfranchisement of the male population in 1912. In particular, the enfranchisement of the non-elites was followed by a decline in voting turnout, much more marked in the Southern regions. We next provide an econometric analysis of this event that is grounded in the theoretical framework discussed in Section 3, particularly result R3.

The starting point of our analysis is equation (5), which relates voting turnout to the electoral participation and relative size of elite and non-elite groups in the electorate. The aim of the econometric exercise will be to identify how $\Delta \pi(\alpha)$ - the differential participation of elites and non-elites - varies across Italian regions and electoral districts characterized by a different degree of civicness $\alpha$, and test whether these empirical patterns conform with the theoretical predictions of the model.

The main source of historical electoral data in Italy is the Atlante Storico Elettorale d'Italia (2009), produced by the Istituto Carlo Cattaneo. ${ }^{7}$ The data set provides information on voting turnout and electoral results for the whole Unitarian period. The geographical detail varies across different periods: regional figures are available for all 37 free elections held since 1861 (plus 3 plebiscites during the fascist period), while district-level information covers the years 1861-1913 ; finally municipality-level data are available for the post-WWII period.

\subsection{Regional analysis}

We focus here on the regional data for all 19 elections held during the period between the Unification and the advent of Fascism (1861-1921). While in principle aggregate electoral data do not allow us to observe the explanatory variable of main interest in equation (5), namely the share of non-elite individuals in the electorate, such a share necessarily decreased in all regions following the enfranchisement of 1912. We may thus exploit this common shock to identify $\Delta \pi\left(\alpha_{r}\right)$, the difference in voting turnout between elites and non-elites in region $r$.

7 The Istituto Carlo Cattaneo is an Italian NGO that has been active for several decades in the collection and analysis of electoral data, see www.cattaneo.org. 
In practice, to estimate equation (5) we regress the voting turnout in region $r$ and election $t$ on an indicator variable Post that takes value 1 for all elections after 1912, and absorb $\pi_{E}\left(\alpha_{r}\right)$ and other time invariant factors into a set of region fixed effects. In this way, the coefficient of Post captures the (average) increase in the share of non-elites after the enfranchisement, $\Delta \pi\left(\alpha_{r}\right)$; letting the estimate vary across regions allows for a differential impact of the enfranchisement across regions characterized by different levels of civicness $\alpha_{r .}{ }^{8}$

The results are presented in Table 3. The first column quantifies the average drop after the enfranchisement in 4.6 percentage points, doubling to 9.3 when we include a linear trend (column 2) to control for the long-run increase in voting turnout that is evident from Figure 2. When we split the sample to distinguish between different areas of Italy (columns 3 and 4), the average drop is more than four times larger in Southern than in Northern regions. The difference-in-differences specification in column (5) confirms that the estimated coefficients are significantly different from each other and quantifies in almost 20 percentage points the additional drop in southern regions; such finding is unchanged as we include a full set of yearspecific fixed effects (column 6).

One threat to the validity of the difference-in-differences approach is the presence of pre-existing differential trends between the two groups of regions, which are indeed apparent from Figure 2. For this reason, in column (7) we allow for area-specific trends, so that the coefficient of the interaction North $x$ Post $t$ captures the post-enfranchisement differential drop net of the long-run differential trends in the voting turnout of the two groups of regions. Even under this very requiring specification, the effect of interest remains strongly statistically significant and of the same order of magnitude.

In principle one cannot rule out the alternative explanation that cultural values themselves changed around the enfranchisement, determining a reversal in voting behavior even in the

\footnotetext{
8 Notice that we are implicitly assuming that civicness is a region-specific characteristic that does not vary over the time period considered here (60 years). This is consistent with a burgeoning literature on the extreme persistence of cultural traits (Guiso, Sapienza and Zingales (2008, 2009, 2010), Nunn and Wantchekon (2009), Durante (2009) and Guiso, Sapienza and Zingales (2010) for a review), as well as with additional evidence presented later in this section.
} 
absence of any "civicness-mediated" effects of (changes in) electoral institutions. While this alternative explanation contrasts with a burgeoning literature on the slow moving and persistent nature of cultural traits (Guiso et al., 2010 for a review), we nevertheless explore this possibility by examining the persistence over time of an observable measure of civic traditions across Italian regions, namely the incidence of voluntary associations already described in Figure 1. Therefore, in Figure 4 we plot the same measure for years 2001 and 1883, as reported by the last available Census and by the Italian Ministry of Agriculture, Industry and Commerce, 1885, respectively; the graph does not suggest any reversal in civicness between Northern and Southern.

In the last two columns of Table 3 we re-estimate the same specification plugging the incidence of voluntary associations, as an observable measure of civicness, in place of the crude distinction between northern and southern regions. The results are qualitatively similar but lower in magnitude. In particular, the estimated coefficient in column (8) implies that an increase in the incidence of voluntary associations equal to the difference between north and south (0.3 and 0.9 associations per 10,000 inhabitants, respectively) is associated with a differential increase in voting turnout of $10 \%$ after the enfranchisement, which is lower than the corresponding difference-in-differences between the two groups of regions (column 6). This suggests that the difference-in-differences estimates may partly capture variation along other dimensions in addition to civic traditions.

We try to reduce the scope for spurious effects by inserting additional control variables on the right-hand side of the equation. Besides region-specific and year-specific factors, in fact, there are other possible determinants of voting turnout that differ between northern and southern regions and whose impact may vary under alternative electoral regimes. In particular, correlates of economic development such as human capital and industrialization are likely related to civicness and can also shape the response of non-elites to the enfranchisement.

Therefore, we have collected literacy rates and measures of industrialization from the 1911 Italian census (i.e. around the period of the enfranchisement) and interact them with Post $_{t}$ on the lefthand side of equation (6); the results are presented in Table 4. Controlling for literacy has little or no effect on the difference-in-differences between Northern and Southern regions, while it halves 
the estimated coefficient of interest when civicness is measured by the number of voluntary associations (columns 1 and 5, respectively); the same is true when we control for the level of industrialization, as measured by the number of firms and people employed in industry over total population (columns 2 and 6) or, alternatively, by per-capita energy consumption in each region (columns 3 and 7). However, the drop in the coefficient could be due to the fact that part of the effect of better civic traditions on voting turnout may go through higher human capital and economic development. ${ }^{9}$ In any case, the estimated coefficient of civicness remains statistically significant, even when we control for all variables at the same time (columns 4 and 8).

\subsection{Heterogeneity in enfranchisement rates}

The regional analysis conducted so far confirms that the reversal in voting turnout displayed in Figure 2 is statistically significant and robust to controlling for several other determinants of electoral participation. To provide a definite test of the model, we next relate changes in voting turnout to the fraction of newly enfranchised non-elite potential voters, i.e. the "treatment intensity" of enfranchisement, across electoral districts within the same area.

In general, the size of elite $\left(E_{i t}\right)$ and non-elite groups $\left(N_{i t}\right)$ in each $i$-th district remains unobserved; the only thing that can be observed is total electorate, which equals the sum of the two groups in the elections after the enfranchisement $\left(T_{i t}=E_{i t}+N_{i t}\right)$ and the sole elite group before the enfranchisement of non-elites $\left(T_{i t}=E_{i t}\right)$. Yet, Larcinese (2011) noticed that, narrowing the time window to the period between the last pre-enfranchisement $(t-1=1909)$ and the first postenfranchisement election ( $t=1913)$, the share of newly enfranchised non-elites $n_{i t}$ can be approximated by the relative increase in the electorate between the two elections,

$$
n_{i t}^{*}=\frac{T_{i t}-T_{i t-1}}{T_{i t}}=\frac{N_{i t}+E_{i t}-E_{i t-1}}{T_{i t}}=n_{i t}+\tilde{n}_{i t}
$$

with $\tilde{n}_{i t}$ denoting the change in the number of elite individuals around the enfranchisement over the total post-enfranchisement electorate, $\left(E_{i t}-E_{i t-1}\right) / T_{i t}$. As the latter term remains likely small for

\footnotetext{
${ }^{9}$ Indeed, faster human capital accumulation is considered one of the main payoffs of higher social capital accumulation, see e.g. Knack and Keefer (1997).
} 
the few years between two consecutive elections, the growth of total electorate $n_{i t}^{*}$ provides a good approximation for the share of non-elite voters in the first post-enfranchisement election.

Figure 5 shows that the approximate share of non-elite voters across electoral districts displays substantial variation both within and between Northern and Southern regions; in particular, the distribution is concentrated around higher values in the latter group. On the one hand, this fact supports the results in Table 3 and Table 4 as a test of the theoretical prediction R1, namely that the elites vote more than the non-elites; in fact, (southern) regions characterized by a greater share of elite voters exhibited a stronger decrease in voting turnout after the enfranchisement. Omitted variation in the share of newly enfranchised voters, however, detracts from the credibility of the same estimates as a test of prediction R2, namely that civicness drives the differential response of voting turnout to the enfranchisement of non-elites. Lower treatment intensity rather than higher civicness could in fact explain the lower drop observed in northern regions.

To reduce the scope for omitted variable bias, we augment the specification with the log number of people in the electorate in each region-election; after controlling for common time effects and other determinants of voting turnout, differences in enfranchisement rates across regions constitute the main source of within-region changes in the size of the electorate over the sample period. The results in Table 5 confirm that a greater expansion of the electorate is associated with an average decrease in voting turnout; still, the coefficients of interest are basically unaffected relative to the estimates reported in Table 3 and Table 4.

While this additional evidence suggests that the differential effect between northern and southern regions is not entirely driven by heterogeneity in enfranchisement rates, as opposed to differences in civic traditions, it provides no clear answer about the role played by each of these two factors on the differential changes in voting turnout observed after the enfranchisement in northern and southern regions. To provide such an answer, we narrow the focus on changes between elections immediately before and after the enfranchisement and exploit variation at a finer level of geographical disaggregation. 


\subsection{Non-elites and voting turnout}

Variation across electoral districts in enfranchisement rates and changes in voting turnout between 1909 and 1913 (the last pre-enfranchisement and the first post-enfranchisement election, respectively) provides an additional source of variation to identify the relationship between civicness and participation by the non-elites after the enfranchisement. To provide a precise test of the theoretical model, we take differences of equation (5) between elections in $t=1913$ and $t$ $1=1909$; noticing that $n_{i-1}=0$ (as the non-elites were not allowed to vote before the enfranchisement) and plugging approximation (6) for $n_{i t}$ we obtain the following estimating equation for within-district changes in voting turnout,

$$
V_{i t}-V_{i t-1}=-\Delta \pi\left(\alpha_{r}\right) n_{i t}^{*}+v_{i t}
$$

where $v_{i t}=-\Delta \pi\left(\alpha_{r}\right) \tilde{n}_{i t}$. Equation (7) thus allows us to identify the difference $\Delta \pi\left(\alpha_{r}\right)$ in the electoral participation of elites and non-elites exploiting variation across electoral district within the same area, which considerably reduces the scope for omitted variable bias.

Figure 6 fits regression (7) across electoral districts within northern and southern regions. Consistently with prediction R1 of the theoretical model, both regression lines are negatively sloped; moreover, and in line with prediction R2, the slope is steeper within southern than within northern regions. These patterns mirror those in Figure 3 for individual voting and political participation by socio-economic status.

The OLS estimates reported in Table 6 quantify these visual insights. According to the univariate regression in column (1), a one percentage point increase in the share of the non-elites in the electorate is associated with a 0.36 percentage points decrease in voting turnout; put differently, belonging to the non-elites lowers the probability of voting by one third. Notice also that the estimated intercept is positive, meaning that the observed drop in voting turnout after the enfranchisement is indeed attributable to the lower participation rates of non-elite masses, in the absence of which voting turnout would have followed the same upward trend as in the previous elections. 
Since equation (7) is estimated in first differences, it implicitly controls for all district-specific factors that do not vary over time. However, we might also want to control for local shocks and other factors that impact differentially on voting turnout before and after the enfranchisement. As no economic and social characteristics are available at the district-level, we rather include a full set of regional fixed effects in the first-differenced equation, thus keeping constant all regional shocks and/or regional conditions that could affect the (asymmetric) response of voters to the enfranchisement. The coefficient of interest is only slightly reduced in absolute value (just below 0.3 ) and remains strongly statistically significant.

As we split the sample and estimate the equation across electoral districts within each area, the effect is four times smaller in the civicness-rich northern regions than in the civicness-poor southern regions (columns 3 and 4, respectively). The implied average effects of enfranchisement across districts in the two groups of regions, based on this simple specification, equals 2.3 and 12.8 percent, respectively, thus explaining most of the drop in voting turnout observed in northern and southern regions after the enfranchisement (see columns 3 and 4 of Table 3). The interaction coefficient in column (5) confirms that the difference in the slopes is statistically significant at the 99\% confidence level; an analogous result holds when interacting the share of non-elites with the other measure of civicness, namely the incidence of voluntarily associations.

In the bottom part of Table 6 we examine to which extent the results depend on measurement error and/or the presence of influential observations, as the visual evidence in Figure 6 suggests that these might both be potential issues. In particular, in the middle panel we weight observations by the size of the electorate after the enfranchisement (between 8 and 43 thousand individuals), while in the bottom panel we apply the data-driven algorithm devised by Huber $(1964,1981)$, which iteratively re-weight observations to downplay the importance of outliers. In both cases, the estimates are extremely similar to the OLS ones.

Overall, the results in Table 6 provide empirical support for the main predictions of the empirical model, namely that: the non-elites vote less than the elites; the difference in voting turnout between the two groups is greater the lower is the level of civicness; finally, and most importantly, such differences explain the reversal in voting turnout between northern and 
southern regions after the enfranchisement of the male population in 1912. We conclude this section by looking at the political consequences of the differential response of the non-elites to the extension of voting rights.

\subsection{Reallocation of political power}

The evidence so far is consistent with the view that for democratization to be successful it is required that non-élites are ready and willing to participate in the political process when the reform grants them voting power: but this willingness and readiness depends in turn on whether a culture of civicness is already diffuse. Lacking the latter, non-élites may fail to benefit from the new potential political influence leaving the distribution of powers unchanged and thus certifying a de facto failure of the democratization reform. To inquire this issue more directly we study how non-élites voted once they were granted democratic rights. Arguably, a democratization reform is successful if non-élites make an extensive use of these rights and if their votes are not captured by pre-existing élites but are used to strengthen their representativeness. That is, the reform is successful if it generates a substantial reallocation of political power away from élites.

Socialist and communist parties represented the traditional political outlet of non-elite popular masses in Italy. Starting with the beginning of the $20^{\text {th }}$ century, they went to replace the so-called sinistra storica ("historical left"), which represented the progressive trends among the élites and dominated the political scene in Italy during the last quarter of the $19^{\text {th }}$ century. This process received undoubtedly an impulse after the enfranchisement of the non-elite masses. More precisely, after a slight increase in voting turnout at the first post enfranchisement elections, radical parties doubled their combined electoral share between 1913 and 1919, see Figure 7. This was made possible by the change in the electoral system, from majoritarian to proportional, which weakened the position of incumbent politicians to the advantage of younger political formations; it was also favored by the spread of radical political ideas among soldiers during World War I (Atlante Statistico Elettorale, 2009).

Yet, the same graph shows that the political change was far from uniform. Radical parties gained in fact a significant political power (almost half of the votes in the last elections before the 
fascism) in Northern regions only, where the enfranchisement resulted into an effective increase in the political participation of the non-elites; by contrast, the electoral share of the same parties in southern regions remained always below $15 \%$.

These patterns are confirmed in Table 7, where we regress the voting share of socialist and communist parties on voting turnout. Since the emergence of such parties occurred mainly in the Biennio Rosso between 1919 and 1921 (the "Two Red Years"), we focus on regional data (available for all elections), as opposed to the district-level ones (which are not reported in the Atlante Statistico Elettorale for the period after 1913). While higher voting turnout is associated with a greater electoral success of leftist parties throughout all the period (column 1), the relationship is much stronger after the enfranchisement (column 2). After controlling for region and election fixed effects, a differential percentage point increase in participation raises the electoral stake of radical parties by 0.3 percentage points on average, but by twice as much after the enfranchisement. One obvious interpretation of this finding is that increases in turnout after the enfranchisement were mainly driven by greater participation of the newly enfranchised non-élite masses, which represented the major constituency of socialist and communist parties. These results are unaffected when we control for other correlates of the political support for such parties, namely union density and the incidence of workers' strikes (columns 3 to 5).

We finally compare these findings with those of Larcinese (2011), who also investigates the effect of the enfranchisement on the electoral support enjoyed by radical parties. Contrary to the results in the present paper, however, he finds that the extension of voting rights had little or no effect on the power of such parties. If anything, he finds actually a slight increase in southern regions only, in stark contrast with the picture that emerges from Figure 7. The explanation lies in the fact that, differently from our analysis, he considers the 1909-1913 elections only, in order to fully exploit district-level variation in the share of non-elite voters. In this way, however, he misses most of the variation in the electoral share of socialist and communist parties during the subsequent decade. For this reason, we chose instead to prolong the series through 1921 (even though at the cost of a lower geographical detail). 


\subsection{The post-war period: political elections vs. popular referenda}

Overall, the results presented so far show that "de jure" concession of political rights taking place with the franchise resulted into a "de facto" re-allocation of political power only in the regions where non-elites were willing to actually exert those rights. One wonders whether this difference in civicness disappears over time as people voted repeatedly and possibly learned how to benefit from extended democratic rights. Put differently, did the 1912 extended franchise to the male population and the subsequent extension of voting rights to the whole population independently of gender after WWII bridge the gap in people civicness across regions of the country? After all, the main explanation that has been forward to explain why civicness differs so much between the North and the South of Italy is Putnam (1993) story. He was the first to argue that the civic capital divide between the North and the South of Italy aroused when history in these two parts of the country bifurcated around the turn of the first millennium. The North experienced for centuries a system of free cities that allowed its citizens to participate in the political process and to learn the benefits of democratic involvement which crystallized into people's culture. The South instead ended up being dominated by highly hierarchical governments that never involved non-elites in political decisions and political management until Italy's unification in 1861. Non-élites, the story goes, have thus internalized norms of dependence from élites and of non-involvement in the making of collective decisions. Have a century of democratic concessions and formal democratic rights bridged the civicness gap?

One simple way to address this question is to compare the gap in participation in parliamentary elections between South and North since the 1912 franchise. The first national elections after the promulgation of the Constitution, held in 1948, were still characterized by a higher voting turnout in Northern than in Southern regions; even though the difference between the two areas was initially relatively narrow, the gap widened considerably over the following 60 years, see Figure 2. On this account, there seem to be no convergence in civicness.

A possibly better way is to look at differences in participation in political elections and in referenda after WWII. Popular referenda - first introduced with 1946 republican constitution differ from political elections because they call citizens to decide directly on subjects of public 
interest, such as divorce and abortion, public funding to political parties or reliance on nuclear power to produce energy. Referenda are often promoted by groups of citizen without any direct intermediation of members of political parties. Therefore, the opportunity for rent-seeking offered by participation in referenda should be absent (or at least much more limited) relative to political elections. Indeed, it is exactly for this reason that turnout in referenda (as opposed to national elections) has been traditionally used as a genuine measure of civic capital (see for instance Putnam, 1993; Guiso et al., 2004 and 2010b). Because of this, the difference in participation behavior between popular referenda and national elections provides also an alternative way to test the predictions of our theoretical framework.

In terms of the simple model in (1)-(2), imposing $R=0$ in popular referenda for all individuals (including the élites), equation (5) implies that the difference in turnout between parliamentary elections $\left(V^{p}\right)$ and referenda $\left(V^{r}\right)$ should be

$$
\mathrm{V}^{\mathrm{p}}-\mathrm{V}^{\mathrm{r}}=\mathrm{n} \pi_{\mathrm{N}}(\alpha)+(1-\mathrm{n}) \pi_{\mathrm{E}}(\alpha)-\pi_{\mathrm{N}}(\alpha)=(1-n) \Delta \pi(\alpha)
$$

Therefore, from predictions R1 and R2 (equations 3 and 4, respectively) we expect the difference in (8) to be positive and greater in less civic regions. Hence, if the extension of voting rights started with the 1912 franchise and completed with the 1946 constitution has contributed to bridge the civicness gap we should find that the difference in participation between political elections and referenda that have taken place after WWII is similar in Southern and in Northern regions. If instead democratic concessions did not contribute to the spread out of a civic culture, our model predicts a persistent and larger gap in the South between the two types of participation.

To test these predictions we assemble data on political elections and referenda in the postwar period. We use data on all the referenda that took place between 1974 and 1995 (see Table 7). The 1974 referenda on divorce was the first to take place after the 1946 referendum following the collapse of fascism for the choice between a constitutional monarchy and a republic. We choose to disregard this first referendum for two reasons: first, because participation was presumably affected by the intensity of the presence of the war across Italian regions and the differences that 
this triggered in people sentiments towards monarchy. Second, because looking at referenda that took place starting between 30 and 50 years after the formation of the democratic republic we allow for democratization to have had sometime to exert its effects on people's civic culture. We exclude referenda that took place after 1995 because, due to abuse of this institute, most these referenda did not achieve the quorum. ${ }^{10}$ We then compute the difference in participation in referenda and in the nearest parliamentary election across regions.

Figure 8 shows the comparison between voting turnout in each referendum between 1974 and 1995 with its closest national election; consistent with the prediction in (8), with one exception (Northern regions in the 1993 referendum) participation is always higher in national elections and the difference is always greater in southern regions. Furthermore, the South-North gap in the participation premium between parliamentary elections and referenda is basically unchanged through the whole period. This last finding suggests that democratization per sè does not seem to have been able to affect people civic culture after half a century of exercise of voting rights and almost 20 opportunities to vote between 1975 and 1995, including municipal and European parliament elections.

\section{Conclusions}

Using historical data on democratization and voting turnout in Italy we find that the 1912 franchise led to a lower average participation in political elections but the decrease was much larger in the South than in the North to the point that a reversal emerged and the gap has since never been bridged. We interpret these results in the context of a simple model where participation in politics is driven both by a private motive for the potential benefit that involvement with power may give rise to and a social motive induced by pre-existing civic culture.

\footnotetext{
${ }^{10}$ More specifically, after 1995 it became common for the opposers of the proposals to boycott the ballot (rather than voting "NO") in order to have the referendum missing the quorum. The referendum is not valid, in fact, unless at least $50 \%$ of the electorate votes. By adopting this strategy, the supporters of "NO" may take advantage of some natural rate of abstention that is present in any election.
} 
These findings have two implications: first, a process of formal democratization through the concession of voting rights to a larger segment of the population is less likely to succeed and may indeed fail to work altogether if the beneficiaries of the new rights lack the civic culture necessary to practice these rights and translate them into effective political participation. Democratic reform supplies the potential for democratization, but its ultimate success rests on the existence of a demand for political participation based on the new voter's actual willingness to use democratic rights: but to arise this demand requires a pre-existing civic culture, as argued long ago by Almond and Verba (1963). The second point is that democratization seems also to fail to produce civic culture in such a way as to fill the gap between the two areas of the country: after decades of experimentation with democracy and repeated voting in local, national and European elections, as well as in referenda, the gaps in political participation and in civic engagement between the North and the South remain unchanged. This raises one important question: can this lack of influence be consistent with the idea, first proposed by Putnam (1993) and supported by the evidence in Guiso et al. (2010), that the difference in civic values between the North and the South reflects difference in exposure to democracy and familiarity with participation in the management of the public good that dates back to the experience of the free cities in the cities of the North? Why the free city experience of democratic engagement has affected people civic culture while the concession of democratic rights did not? One possibility is that the free city experience lasted for about three centuries, much longer than the practice of universal suffrage after 1912. The latter may be too short to dismantle a culture of weak involvement which tends to be transmitted from generation to generation and, as such, shows persistence. A second explanation is that while the 1912 suffrage was a concession of an elite, perhaps to avoid bigger transfers of power under the threat of a socialist revolution (Acemoglu and Robinson (2000)), the emergence and invention of democratic participation in the free cities was the results of a big historical shocks - the collapse of the Holy Roman Empire and the disorder that followed - that required people's direct involvement in the management of the public good. This would suggest that a civic culture - "a set of beliefs, attitudes, norms, perceptions and the like, that support participation" (Almond and Verba, p. 178) - is more likely to emerge when circumstances require that not only elites but the whole population or very large segments take responsibility in the solution of collective action problems. 


\section{References}

Acemoglu, Daron, Simon Johnson, Amir Kermani, James Kwak and Todd Mitton (2010). "The value of political connections in the United States", Working paper

Acemoglu, Daron, S. Johnson and J. A. Robinson (2001), "The Colonial Origins of Comparative Development: An Empirical Investigation", American Economic Review, v. 91(5), pp. 13691401

Acemoglu, Daron and S. Johnson (2005), “Unbundling Institutions”, Journal of Political Economy, v. 113(5), pp. 949-995

Acemoglu, Daron. and J. A. Robinson (2008), "Persistence of Power, Elites and Institutions", American Economic Review, v. 98(1), pp. 267-93

Acemoglu, Daron. and J. A. Robinson (2000), “Why did the West extend the franchise? Democracy, inequality and growth in historical perspectives", Quarterly Journal of Economics, v. 115(4), pp. 1167-1199

Almond, Gabriel Abraham and Sidney Verba (1963), The Civic Culture: Political Attitudes and Democracy in Five Nations, Princeton University Press, Princeton NJ

Atlante Storico Elettorale d'Italia (2009), Zanichelli Editore, Bologna

Banfield, E. (1958), The Moral Basis of a Backward Society, Free Press, New York.

Diermeier, Daniel, Michael Keane and Antonio Merlo (2005). "A Political Economy Model of Congressional Careers," American Economic Review, v. 95(1), pp. 347-373

Durante, R., (2009), “Risk, Cooperation and the Economic Origins of Social Trust: An Empirical Investigation", Working Paper.

Ferguson, Thomas and Hans-Joachim Voth, (2008), "Betting on Hitler-The Value of Political Connections in Nazi Germany," The Quarterly Journal of Economics, v. 123(1), pp. 101-137

Fisman, Raymond (2001). "Estimating the Value of Political Connections," American Economic Review, v. 91(4), pp. 1095-1102

Guiso, Luigi, Paola, Sapienza, and Luigi Zingales (2004), "The Role of Social Capital in Financial Development", American Economic Review, v. 94(3), pp. 526-556.

Guiso, Luigi, Paola, Sapienza, and Luigi Zingales (2006), “Does culture affect economic outcomes?", Journal of Economic Perspectives, v. 20(2), pp. 23-48

Guiso, Luigi, Paola, Sapienza, and Luigi Zingales (2008) "Social Capital as Culture", Marshall Lecture at the 2007 EEA Meeting in Budapest, Journal of the European Economic Association, April-May 2008: 6, 2-3: 295-320. 
Guiso, Luigi, Paola, Sapienza, and Luigi Zingales (2009), “Cultural Biases in Economic Exchange?", Quarterly Journal of Economics : 124, 3: 1095-1131.

Guiso, Luigi, Paola Sapienza and Luigi Zingales (2010a), “Long-Term Persistence”, CEPR WP

Guiso, Luigi, Paola Sapienza and Luigi Zingales (2010b) , "Civic Capital as the Missing Link", , Handbook of Social Economics, Jess Benhabib, Albero Bisin and Matthew Jackson (Eds.), North Holland, 2010

Greif, A., 2006, Institutions and the Path to the Modern Economy Lessons from Medieval Trade, Cambridge Economic Press.

Knak, S. and P. Keefer (1997), "Does social capital have an economic pay-off? A cross country investigation", Quarterly Journal of Economics, 112.4:1251-1288.

Knack. Stephen and Paul Zak (1999) "Trust and Growth." Claremont University Working Paper

Larcinese, Valentino (2011), “Enfranchisement and Representation: Italy 1909-1913”, London School of Economics

La Porta. Rafael. Florencio Lopez de Silanes. Andrei Shleifer. and Robert Vishny (1998). "Law and Finance." Journal of Political Economy. 1131-1150.

McKitterick, Rosamond (2004), "Atlas of the Medieval World", Oxford University Press, Oxford Milani, Giuliano (2005), "I Comuni Italiani”, Editori Laterza, Bari

Milani, Giuliano (2005), “I Comuni Italiani”, Editori Laterza, Bari

Mills, C. Wright (1945) “The American Business Elite: A Collective Portrait”, The Journal of Economic History, 5 (Supplement), pp. 20-44

Ministry of Agriculture, Industry and Commerce (1888), Statistica delle società di mutuo soccorso e delle istituzioni cooperative annesse alle medesime, Tipografia Matastasio, Rome.

Mosca, Gaetano (1939), “The Ruling Class”, New York, NY: McGraw-Hill.

Murrell, P., and M. Schmidt (2011) "The Coevolution of Culture and Institutions in Seventeenth Century England", mimeo, University of Maryland.

Nunn, N., Wantchekon, L. (2009), "The Slave Trade and the Origins of Mistrust in Africa”, American Economic Review,

Reynolds, Susan (1997), "Kingdoms and Communities in Western Europe 900-1300", second edition, Clarendon Press, Oxford University Press, Oxford.

Putnam, Robert, Robert Leonardi and Raffaella Nanetti (1993), “Making Democracy Work ", New York Simon \& Schuster 
Putnam, Robert (2000), "Bowling alone: The collapse and revival of American Community", New York Simon \& Schuster

Roland Gerard and Yuriy Gorodnichenko (2011a) Which Dimensions of Culture Matter for Long Run Growth? ., American Economic Review. Papers and Proceedings,

Roland Gerard and Yuriy Gorodnichenko (2011b), “Culture, Institutions and the Wealth of Nations", University of California Berkeley working paper.

Tabellini. Guido. (2008a). "Institutions and Culture". The Journal of the European Economic Association. Presidential Lecture to the European Economic Association. April

Tabellini. Guido (2008b). "The Scope of Cooperation: Values and Incentives." Quarterly Journal of Economics. pp. 905-950

Tabellini. Guido (2009). "Culture and institutions: economic development in the regions of Europe." Journal of the European Economic Association. forthcoming.

Williamson, Oliver E. (2000), "The New Institutional Economics: Taking Stock, Looking Ahead" Journal of Economic Literature 38 (3), 595-613. 


\title{
Appendix: list of regional variables
}

\author{
Dependent variables
}

Voting Turnout: share of voters over total electorate in each region-election. Source: Atlante Storico Elettorale d'Italia (2009)

Electoral support to socialist and communist parties: share of votes obtained by such parties over the total valid votes in each region-election. Source: Atlante Storico Elettorale d'Italia (2009)

\section{$\underline{\text { Explanatory variables }}$}

North: indicator variable for northern and centre regions, which were not under the control of the Bourbons before the Unification.

Post: indicator variable for elections held after the enfranchisement of 1912.

Associations: number of voluntarily associations per 10,000 inhabitants in each region in year 1885. Source: Ministry of Agriculture, Industry and Commerce (1888)

Literacy: percentage of people above 21 able to write and read in each region in year 1911. Source: 1911 Census

Firms: number of firms over total population in each region in year 1911. Source: 1911 Census Employed in Industry: share of total population employed in industry in each region in year 1911. Source: 1911 Census

Energy production: per-capita energy produced (in Kilowatt/hours) in each region in year 1911. Source: 1911 Census

Ln(Electorate): $\log$ of the total number of people in the electorate in each region-election. Source: Atlante Storico Elettorale d’Italia (2009)

Union density: union members over total population in each region in year 1911. Source: 1911 Census

Strikes: number of workers involved in strikes over total population in each region in year 1911. Source: 1911 Census 


\section{Figures and Tables}

Figure 1: civic capital across regions in 1883, as measured by the diffusion of mutual aid societies

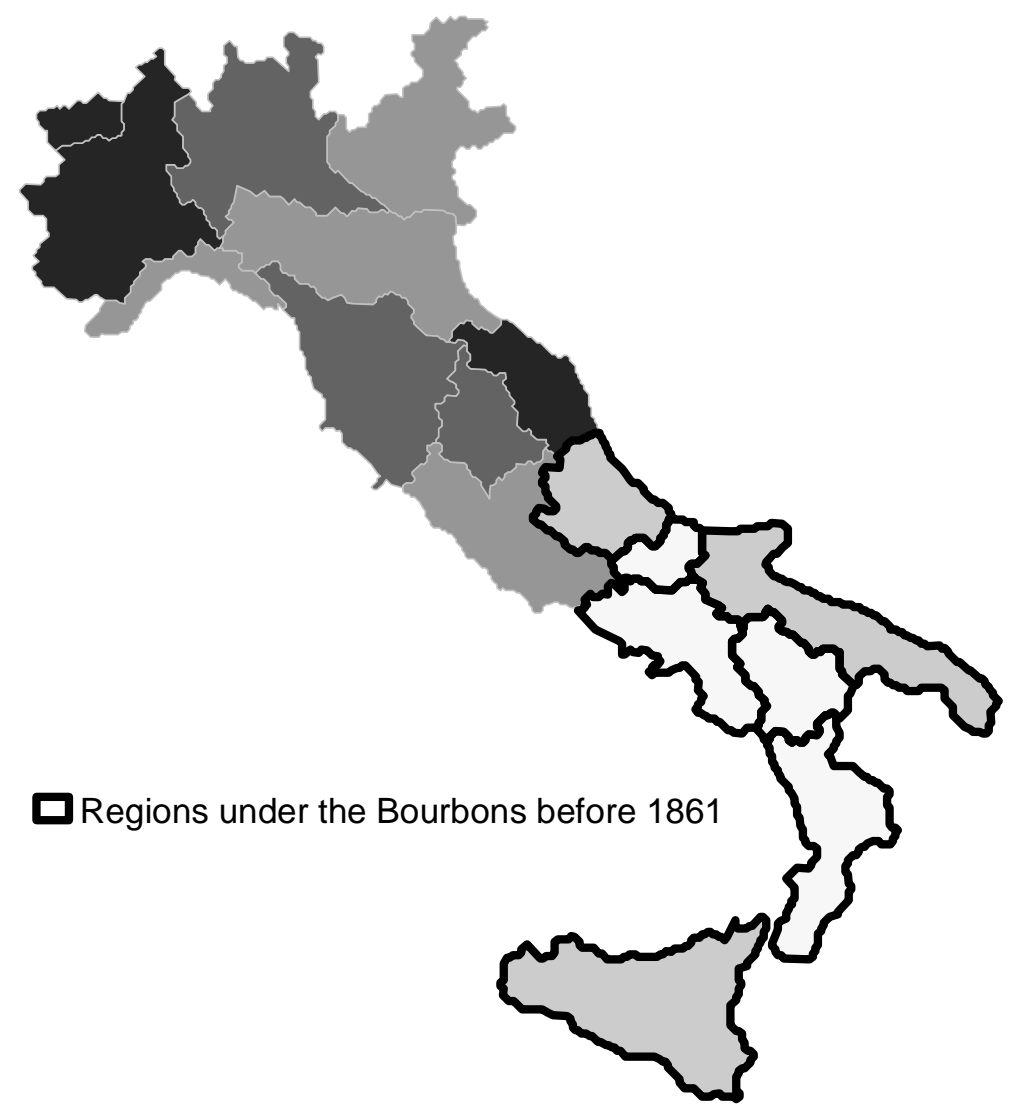

Notes: This figure shows the number of mutual aid societies over population across Italian regions in 1883. Darker colors correspond to greater diffusion. 
Figure 2: voting turnout in northern and southern regions, 1861-2008

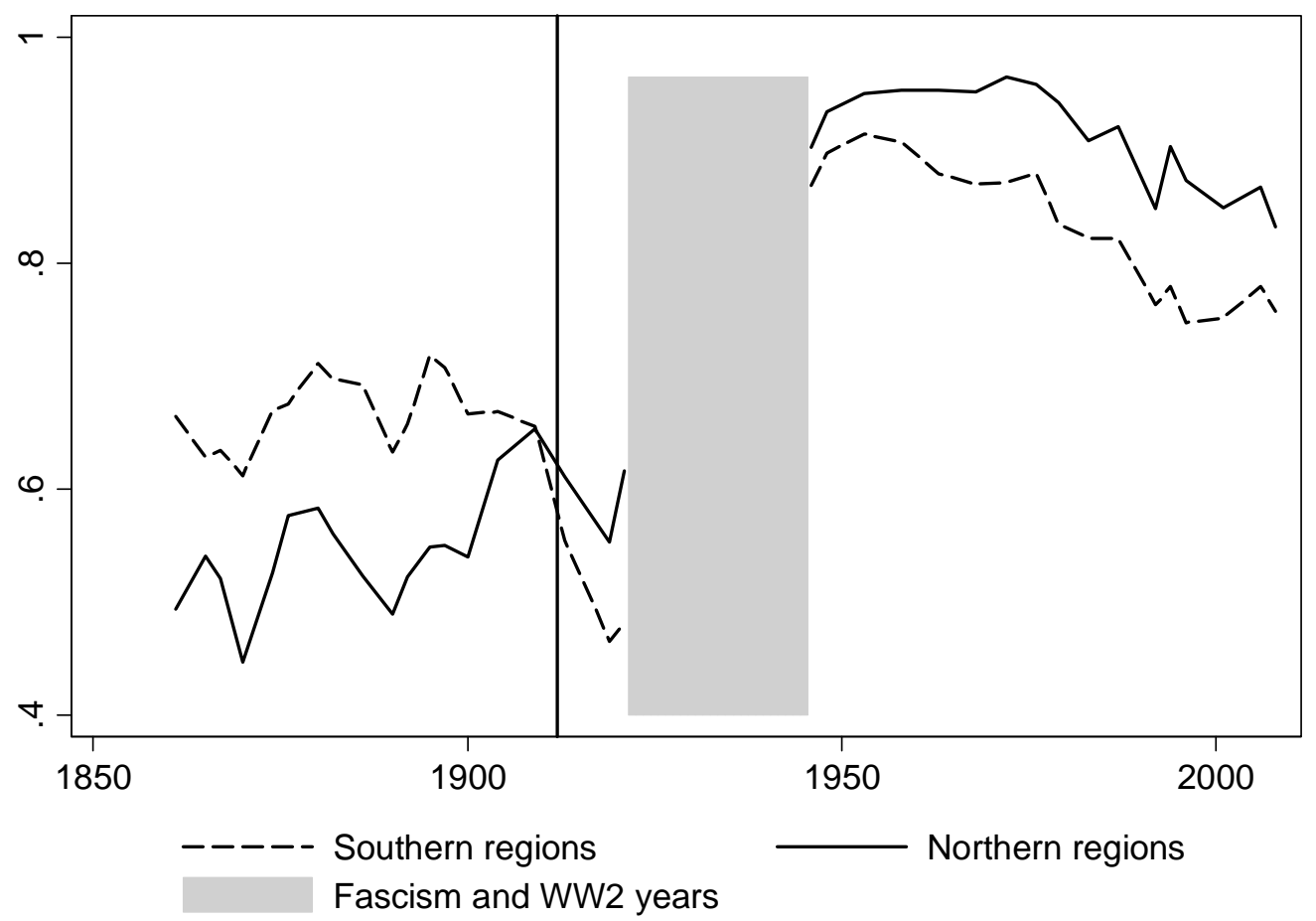

Notes: This figure plots the voting turnout in northern and southern regions during all national elections held since the formation of the Italian state (1861). The vertical line corresponds to the change from restricted suffrage (on an income basis) to the enfranchisement of the entire male population.

Figure 3: political participation in northern and southern regions, by socio-economic status
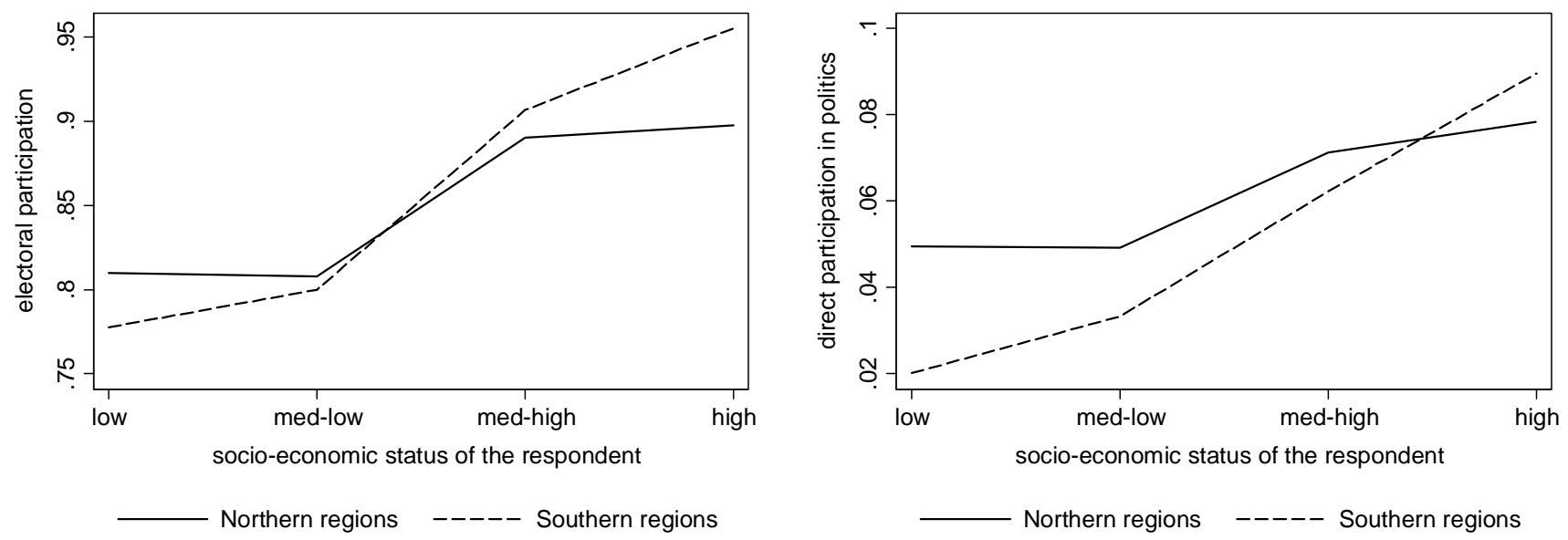

Notes: This figure plots the probability of voting (left graph) and of active participation in politics (right graph) for the sample of individuals interviewed in Italy during the $4^{\text {th }}$ wave of the World Values Survey (year 1999), by respondent's socio-economic status and area of residence. 
Figure 4: incidence of voluntary associations across Italian regions, years 1885 and 2001

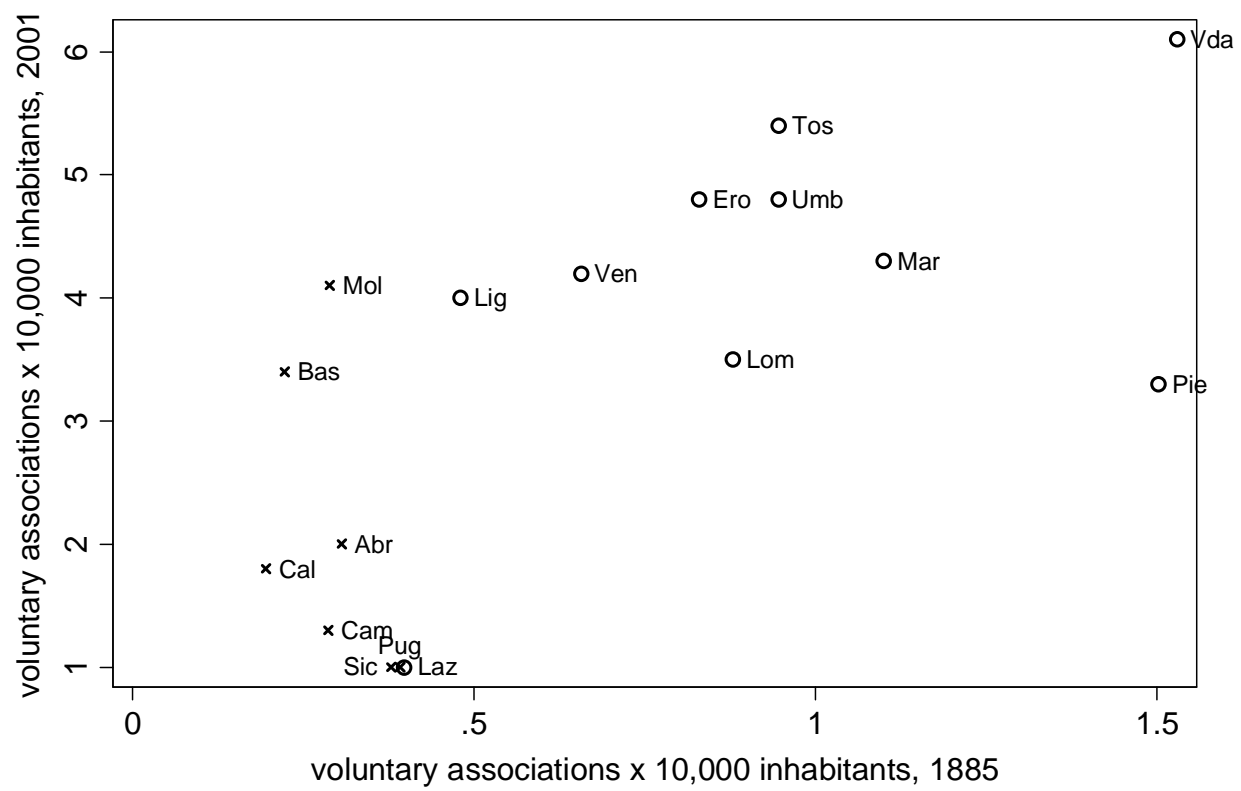

○ Northern regions $\times$ Southern regions

Notes: This figure plots the number of voluntarily associations over population across Italian regions in year 2001 (on the vertical axis) against the same variable in year 1885 (on the horizontal axis). 
Figure 5: approximate share of non-elites among the enfranchised, based on district-level changes in the electorate between 1909 and 1913

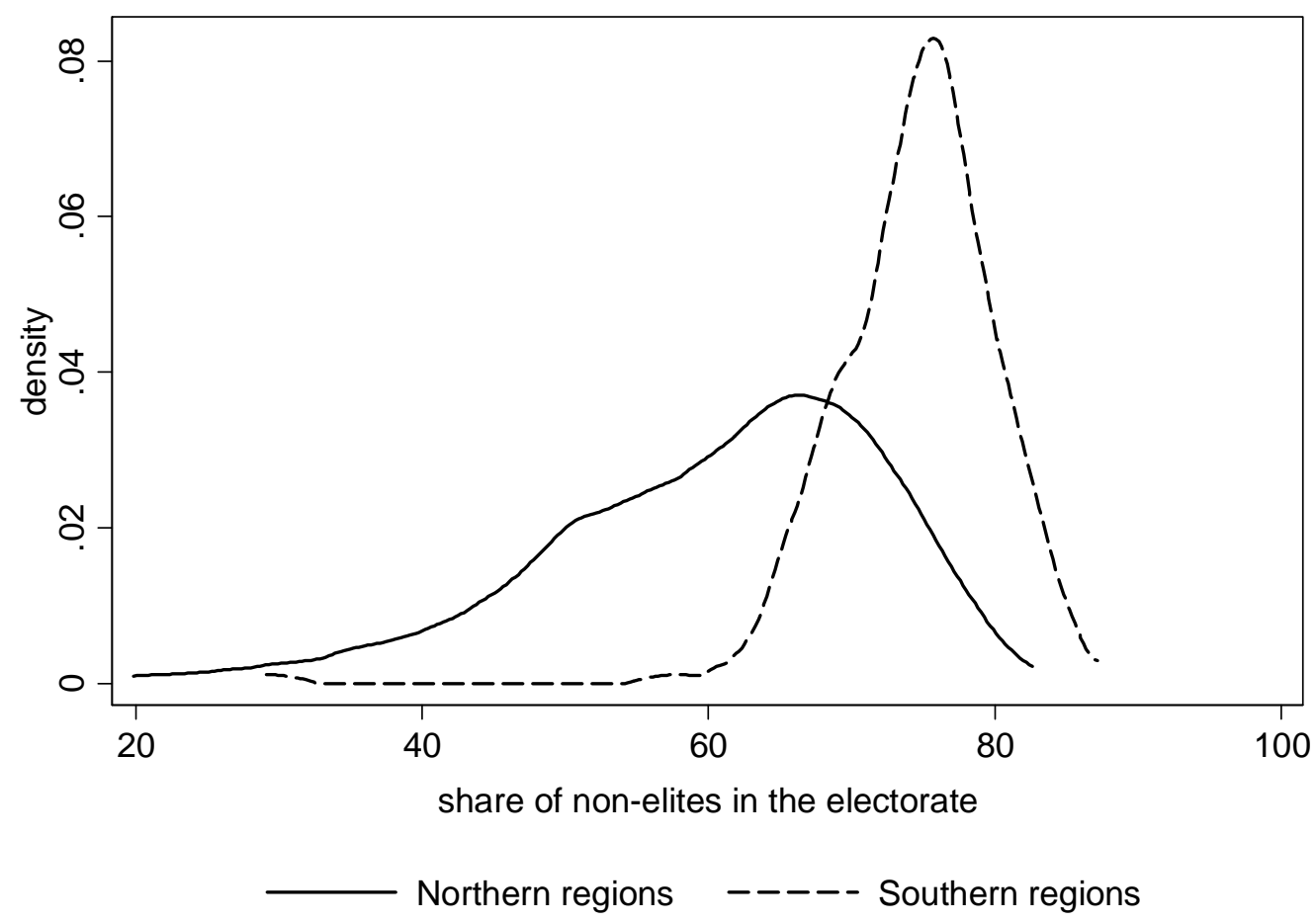

Notes: This figure shows the distribution of the share of non-elite individuals in the electorate across electoral districts, based on the difference in the electorate between the last election before and the first election after the enfranchisement (years 1909 and 1913, respectively) over the total electorate in the latter. 
Figure 6: share of non-elites in the electorate and change in turnout around the enfranchisement (1909-1913)

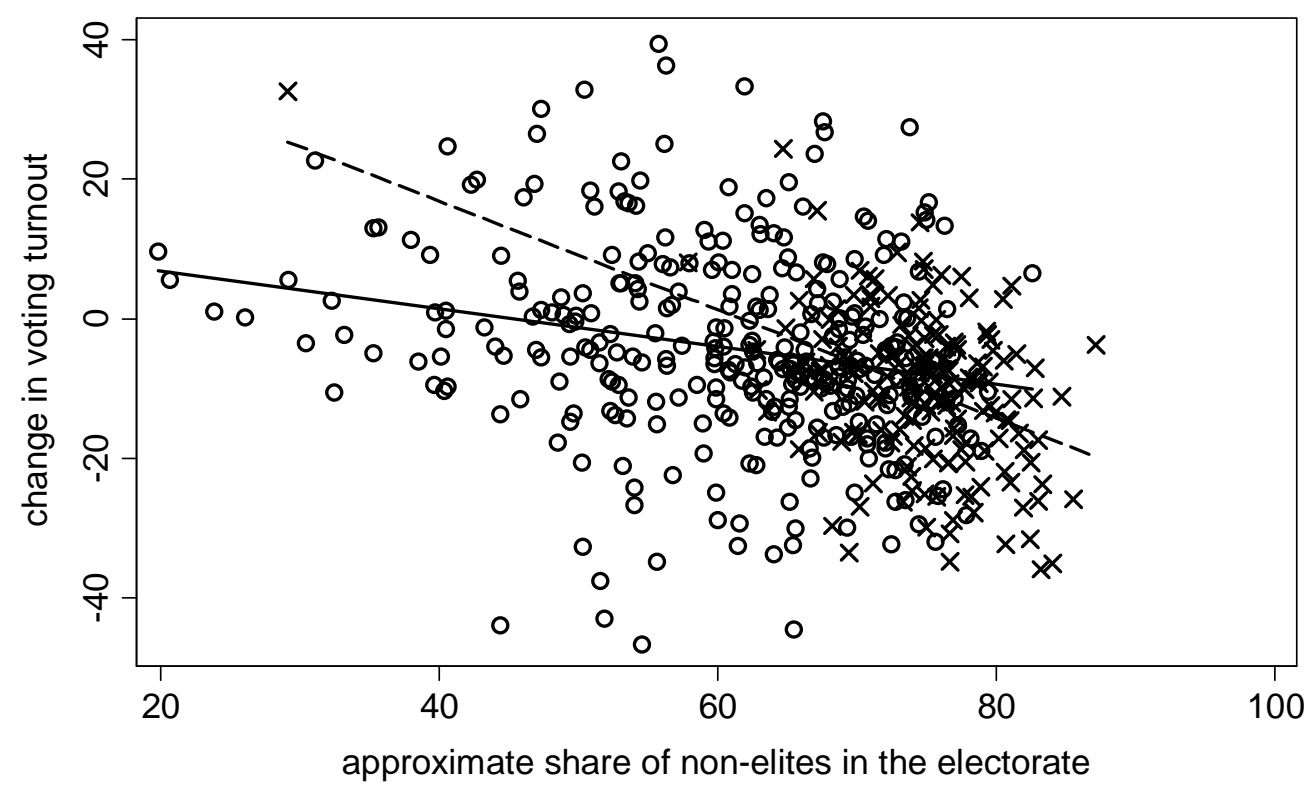

$\begin{array}{cccc}\circ \quad \text { Northern districts } & \times & \text { Southern districts } \\ & \text { North, linear prediction } & ---- & \text { South, linear prediction }\end{array}$

Notes: This figure plots the change in voting turnout between the last pre-enfranchisement and the first post-enfranchisement election (years 1909 and 1913, respectively) against the approximate share of non-elite voters across electoral districts. The share of non-elite voters is estimated by the changes in the electorate between the two elections over the total electorate in 1913. 
Figure 7: share of votes to socialist and communist parties in northern and southern regions, 1861-1921

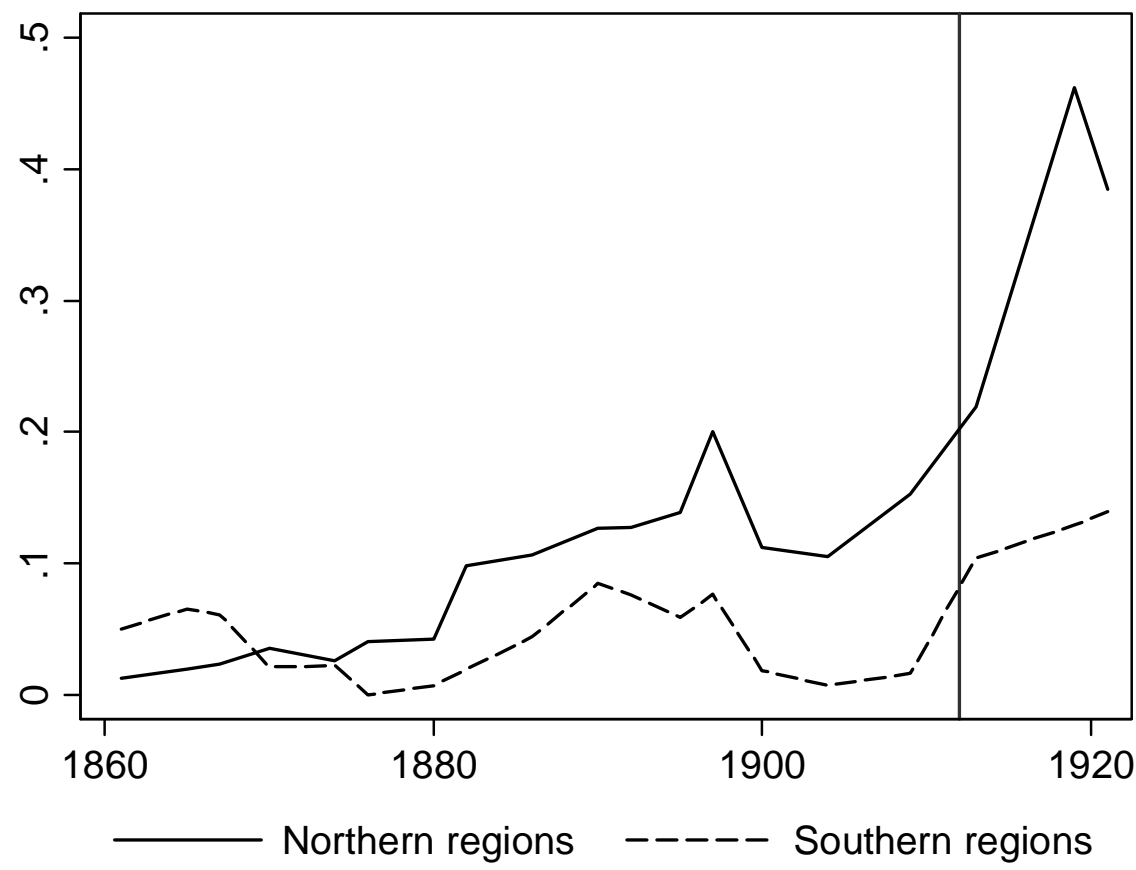

Notes: This figure plots the fraction of voted obtained by socialist and communist parties in northern and southern regions during all national elections held from the formation of the Italian state (1861) to the advent of Fascism (1921). The vertical line corresponds to the change from restricted suffrage (on an income basis) to the enfranchisement of the entire male population. 
Figure 8: gap in voting turnout between political elections and referenda in Northern and Southern regions

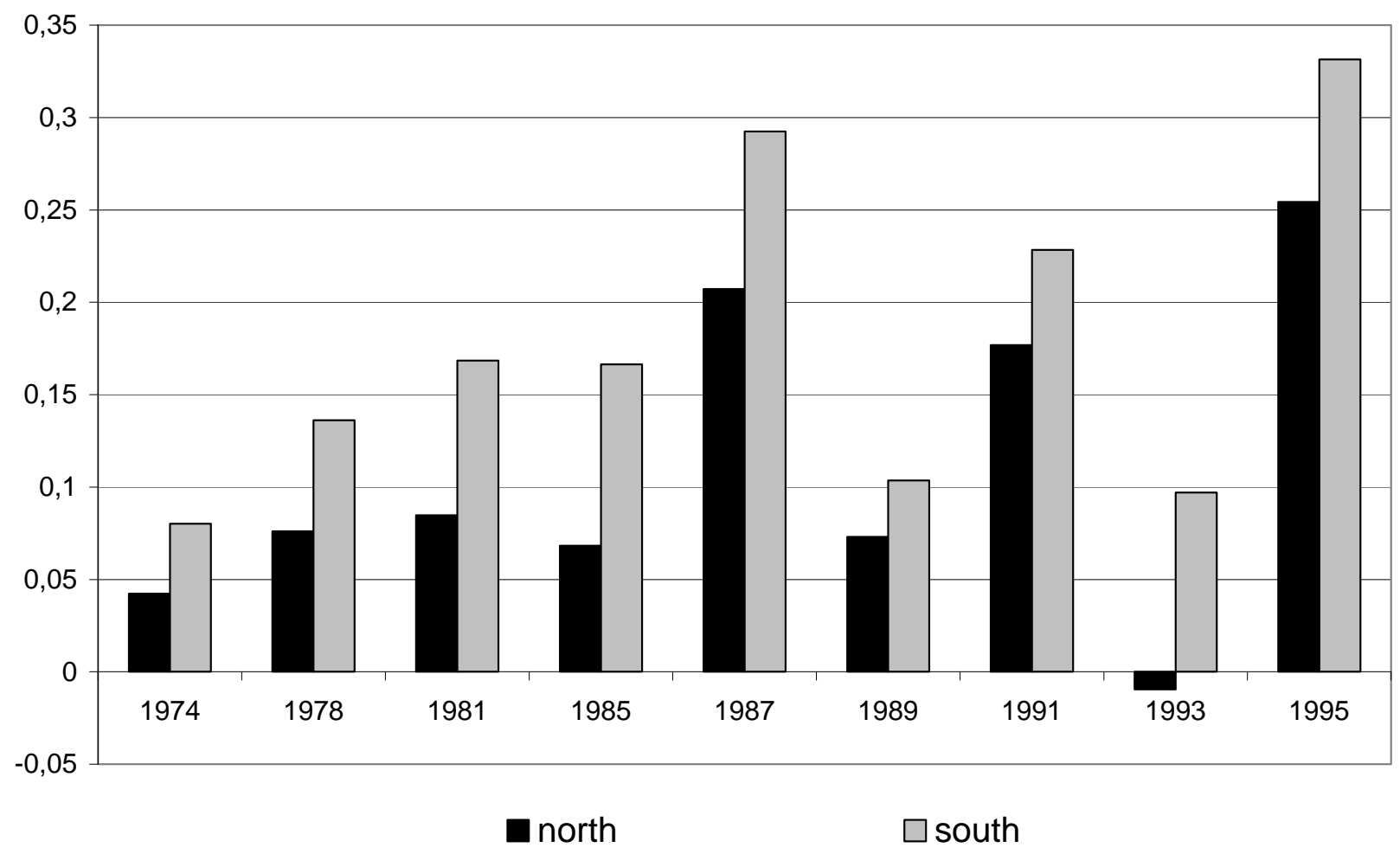

Notes: This figure shows the difference between the voting turnout in national elections and popular referenda in northern and southern regions during the period 1974-1995 (the year on the horizontal axis correspond to the referendum year and the difference is taken with respect to the national election that is closest to that year). 
Table 1: linear probability model for voting behavior

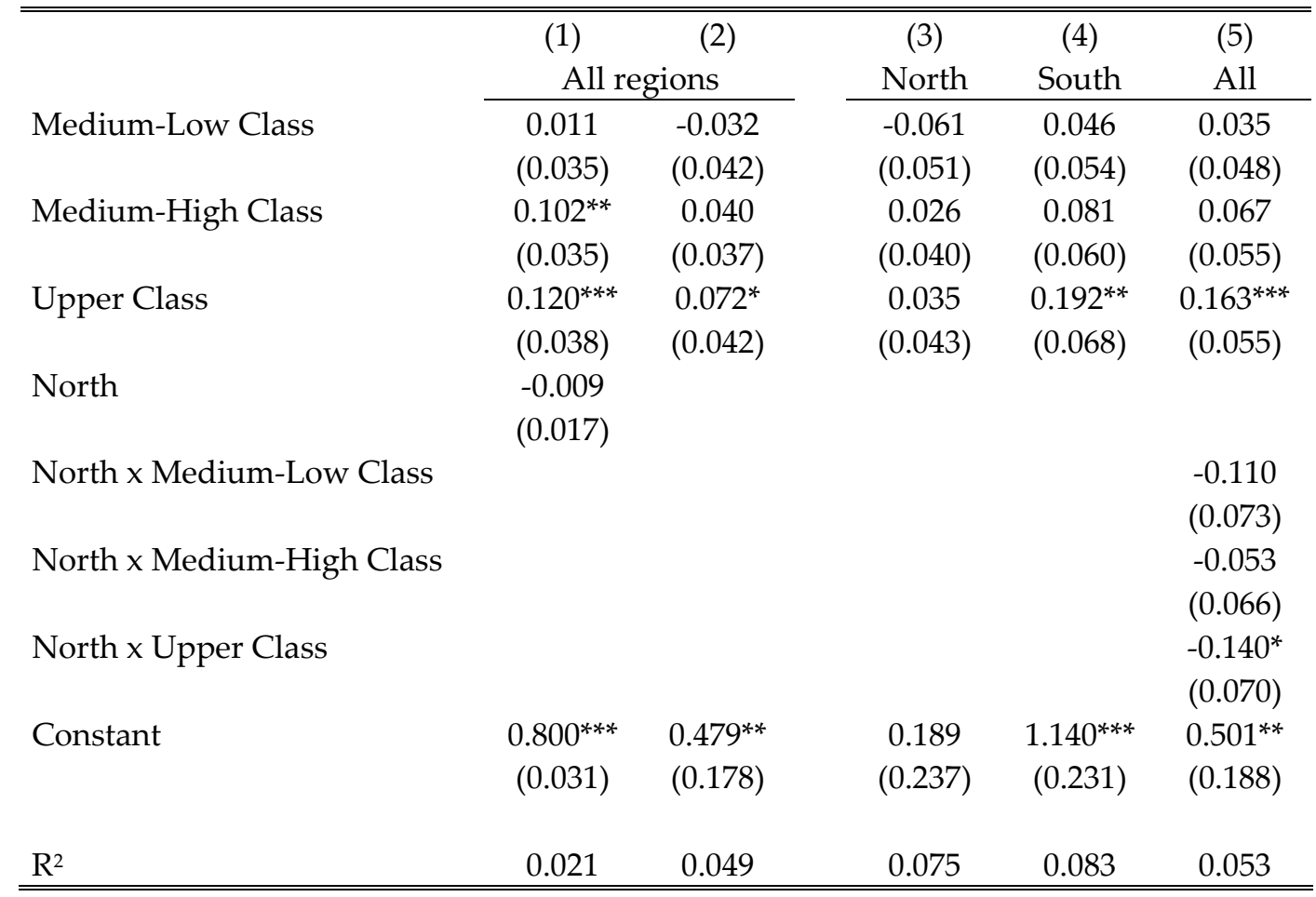

Notes: This table presents OLS estimates of a linear probability model of political participation. The unit of analysis are answers to the World Values Survey for the sample of (up to) 1,304 Italian individuals interviewed during the $4^{\text {th }}$ wave of the survey (year 1999). The dependent variables is an indicator variable for the intention to vote in the next political election. The explanatory variables of main interest are a set of categorical indicators for socio-economic status (4 categories) as well as their interaction with an indicator variable for Northern regions. All specifications include a quadratic polynomial in age, gender and categorical variables for number of children and size of the town of residence, as well as categorical indicators of preferences for democracy whenever indicated ("Additional individual controls"). The table reports whether the regression includes also region fixed effects. Robust standard errors clustered by region are reported in parenthesis; ${ }^{* * *}$ and ${ }^{* *}$ denote coefficients significance at the $90 \%, 95 \%$ and $99 \%$ confidence level, respectively.

Table 2: linear probability model for direct participation into politics

\begin{tabular}{|c|c|c|c|c|c|}
\hline \multirow[b]{2}{*}{ Medium-Low Class } & \multicolumn{2}{|c|}{ All regions } & \multirow{2}{*}{$\begin{array}{c}\text { North } \\
0.013 \\
(0.027)\end{array}$} & \multirow{2}{*}{$\begin{array}{c}\text { South } \\
0.046 \\
(0.025)\end{array}$} & \multirow{2}{*}{$\begin{array}{c}\text { All } \\
0.060^{*} \\
(0.031)\end{array}$} \\
\hline & $\begin{array}{c}0.006 \\
(0.017)\end{array}$ & $\begin{array}{l}0.033^{*} \\
(0.019)\end{array}$ & & & \\
\hline Medium-High Class & $\begin{array}{l}0.031^{*} \\
(0.015)\end{array}$ & $\begin{array}{l}0.062^{* *} \\
(0.022)\end{array}$ & $\begin{array}{c}0.038 \\
(0.033)\end{array}$ & $\begin{array}{l}0.094^{* *} \\
(0.034)\end{array}$ & $\begin{array}{l}0.085^{* *} \\
(0.030)\end{array}$ \\
\hline Upper Class & $\begin{array}{l}0.043^{* *} \\
(0.021)\end{array}$ & $\begin{array}{c}0.045 \\
(0.027)\end{array}$ & $\begin{array}{c}0.001 \\
(0.036)\end{array}$ & $\begin{array}{l}0.116^{*} \\
(0.052)\end{array}$ & $\begin{array}{c}0.120^{* * * *} \\
(0.039)\end{array}$ \\
\hline North & $\begin{array}{c}0.011 \\
(0.014)\end{array}$ & & & & \\
\hline North x Medium-Low Class & & & & & $\begin{array}{l}-0.050 \\
(0.041)\end{array}$ \\
\hline North x Medium-High Class & & & & & -0.045 \\
\hline
\end{tabular}




\begin{tabular}{lccccc} 
North x Upper Class & & & & & $\begin{array}{c}(0.040) \\
-0.115^{* *} \\
\text { Constant }\end{array}$ \\
& & & & & $(0.050)$ \\
& $0.030^{*}$ & $0.188^{*}$ & 0.135 & 0.194 & $0.203^{*}$ \\
& $(0.016)$ & $(0.093)$ & $(0.081)$ & $(0.139)$ & $(0.097)$ \\
N. Observations & & & & & \\
Region FE & 1,304 & 1,049 & 712 & 337 & 1,049 \\
Additional individual controls & NO & YES & YES & YES & YES \\
$\mathrm{R}^{2}$ & NO & YES & YES & YES & YES \\
\hline \hline
\end{tabular}

Notes: This table presents OLS estimates of a linear probability model of political participation. The unit of analysis are answers to the World Values Survey for the sample of (up to) 1,304 Italian individuals interviewed during the $4^{\text {th }}$ wave of the survey (year 1999). The dependent variables is an indicator variable for active involvement in politics, as measured by appointment in office or active membership in some political party (bottom panel). The explanatory variables of main interest are a set of categorical indicators for socio-economic status (4 categories) as well as their interaction with an indicator variable for Northern regions. All specifications include a quadratic polynomial in age, gender and categorical variables for number of children and size of the town of residence, as well as categorical indicators of preferences for democracy whenever indicated ("Additional individual controls"). The table reports whether the regression includes also region fixed effects. Robust standard errors clustered by region are reported in parenthesis; ${ }^{*}{ }^{* *}$ and ${ }^{* * *}$ denote coefficients significance at the $90 \%, 95 \%$ and $99 \%$ confidence level, respectively. 
Table 3: voting turnout before and after the enfranchisement

\begin{tabular}{|c|c|c|c|c|c|c|c|c|c|}
\hline & $(1)$ & (2) & (3) & $(4)$ & $(5)$ & $(6)$ & $(7)$ & $(8)$ & (9) \\
\hline & All re & gions & North & South & All regi & is, differe & ce-in-dif & ences spe & fication \\
\hline Post & $\begin{array}{c}-0.046^{* * *} \\
(0.014)\end{array}$ & $\begin{array}{c}-0.093^{* * *} \\
(0.016)\end{array}$ & $\begin{array}{c}-0.042^{* *} \\
(0.016)\end{array}$ & $\begin{array}{c}-0.176^{* * *} \\
(0.016)\end{array}$ & $\begin{array}{c}-0.209^{* * *} \\
(0.016)\end{array}$ & & & & \\
\hline North $x$ Post & & & & & $\begin{array}{c}0.188^{* * *} \\
(0.018)\end{array}$ & $\begin{array}{c}0.188^{* * *} \\
(0.015)\end{array}$ & $\begin{array}{c}0.134^{* * *} \\
(0.020)\end{array}$ & & \\
\hline North $x$ Trend & & & & & & & $\begin{array}{c}0.002^{* * *} \\
(0.000)\end{array}$ & & \\
\hline Associations $x$ Post & & & & & & & & $\begin{array}{c}0.171^{* * *} \\
(0.023)\end{array}$ & $\begin{array}{c}0.120^{* * *} \\
(0.029)\end{array}$ \\
\hline Associations $x$ Trend & & & & & & & & & $\begin{array}{l}0.002^{* *} \\
(0.001)\end{array}$ \\
\hline Observations & 340 & 340 & 207 & 133 & 340 & 340 & 340 & 322 & 322 \\
\hline Region FE & YES & YES & YES & YES & YES & YES & YES & YES & YES \\
\hline Trend & NO & YES & YES & YES & YES & NO & NO & NO & NO \\
\hline Year FE & NO & $\mathrm{NO}$ & $\mathrm{NO}$ & $\mathrm{NO}$ & $\mathrm{NO}$ & YES & YES & YES & YES \\
\hline $\mathrm{R}^{2}$ & 0.383 & 0.429 & 0.259 & 0.624 & 0.580 & 0.693 & 0.708 & 0.634 & 0.644 \\
\hline
\end{tabular}

Notes: This table presents the results of OLS estimates of the differential effect of the enfranchisement of 1912 on voting turnout across Italian regions. The unit of analysis are region-election observations for 18 Italian regions over 19 national elections during the period 1861-1921 (2 regions did not vote in the first election in 1861). The dependent variable is the fraction of people that voted in each region-election. The main explanatory variables are the indicator variable Post, which is equal to 1 for all elections held after the enfranchisement and 0 otherwise, and two alternative measures of civicness: an indicator variable for regions in the north, which were not under the control of Bourbons before 1861, and the number of voluntarily associations per 10,000 inhabitants in 1885 (this last measure is not available for 1 region in the sample). The bottom part of the table indicates whether the regression includes in addition a linear trend or region and election fixed effects. Robust standard errors are reported in parenthesis; ${ }^{* * *}$ and ${ }^{* * *}$ denote coefficients significantly different from zero at the $90 \%, 95 \%$ and $99 \%$ confidence level, respectively. 
Table 4: voting turnout in northern and southern regions, before and after the enfranchisement (robustness)

\begin{tabular}{|c|c|c|c|c|c|c|c|c|}
\hline & $(1)$ & $(2)$ & (3) & $(4)$ & (5) & $(6)$ & $(7)$ & $(8)$ \\
\hline North $x$ Post & $\begin{array}{c}0.173^{* * *} \\
(0.022)\end{array}$ & $\begin{array}{c}0.146^{* * *} \\
(0.021)\end{array}$ & $\begin{array}{c}0.159^{* * *} \\
(0.021)\end{array}$ & $\begin{array}{c}0.160^{* * *} \\
(0.026)\end{array}$ & & & & \\
\hline Associations x Post & & & & & $\begin{array}{c}0.084^{* * *} \\
(0.030)\end{array}$ & $\begin{array}{c}0.085^{* * *} \\
(0.022)\end{array}$ & $\begin{array}{c}0.103^{* * *} \\
(0.025)\end{array}$ & $\begin{array}{l}0.053^{* *} \\
(0.025)\end{array}$ \\
\hline Literacy $x$ Post & $\begin{array}{l}-0.001 \\
(0.001)\end{array}$ & & & $\begin{array}{c}0.001 \\
(0.001)\end{array}$ & $\begin{array}{c}0.004^{* * *} \\
(0.001)\end{array}$ & & & $\begin{array}{l}0.002^{* *} \\
(0.001)\end{array}$ \\
\hline Firms $x$ Post & & $\begin{array}{c}14.537 \\
(10.391)\end{array}$ & & $\begin{array}{c}11.036 \\
(11.913)\end{array}$ & & $\begin{array}{l}26.560^{*} \\
(14.908)\end{array}$ & & $\begin{array}{c}25.760 \\
(15.845)\end{array}$ \\
\hline $\begin{array}{l}\text { Employed in Industry } x \\
\text { Post }\end{array}$ & & 0.576 & & $0.909^{*}$ & & $1.016^{*}$ & & 0.186 \\
\hline Energy production $x$ Post & & $(0.386)$ & $\begin{array}{l}0.727^{* *} \\
(0.313)\end{array}$ & $\begin{array}{c}(0.519) \\
-0.022 \\
(0.279)\end{array}$ & & $(0.518)$ & $\begin{array}{c}1.496^{* * *} \\
(0.335)\end{array}$ & $\begin{array}{c}(0.628) \\
0.513 \\
(0.328)\end{array}$ \\
\hline Observations & 340 & 340 & 340 & 340 & 322 & 322 & 322 & 322 \\
\hline Region FE & YES & YES & YES & YES & YES & YES & YES & YES \\
\hline Election FE & YES & YES & YES & YES & YES & YES & YES & YES \\
\hline $\mathrm{R}^{2}$ & 0.694 & 0.705 & 0.699 & 0.706 & 0.660 & 0.679 & 0.663 & 0.685 \\
\hline
\end{tabular}

Notes: This table presents the results of OLS estimates of the differential effect of the enfranchisement of 1912 on voting turnout across Italian regions. The unit of analysis are region-election observations for 18 Italian regions over 19 national elections during the period 1861-1921 (2 regions did not vote in the first election in 1861). The dependent variable is the fraction of people that voted in each region-election. The main explanatory variables are the indicator variable Post, which is equal to 1 for all elections held after the enfranchisement and 0 otherwise, and two alternative measures of civicness: an indicator variable for regions in the north, which were not under the control of Bourbons before 1861, and the number of voluntarily associations per 10,000 inhabitants in 1885 (this last measure is not available for 1 region in the sample). Additional controls include interactions of Post with literacy rates, firms over total population, workers in industry over total population and per-capita energy consumption; the source of all these variables is the Italian census of 1911, the detailed description is reported in the Appendix. The bottom part of the table indicates whether the regression includes in addition a linear trend or region and election fixed effects. Robust standard errors are reported in parenthesis; ${ }^{*},{ }^{* *}$ and ${ }^{* * *}$ denote coefficients significantly different from zero at the $90 \%, 95 \%$ and $99 \%$ confidence level, respectively. 
Table 5: voting turnout before and after the enfranchisement, controlling for changes in the electorate

\begin{tabular}{lcccccc}
\hline \hline & $(1)$ & $(2)$ & $(3)$ & $(4)$ & $(5)$ & $(6)$ \\
\cline { 2 - 7 } North x Post & $0.188^{* * *}$ & $0.183^{* * *}$ & $0.160^{* * *}$ & & & \\
Associations x Post & $(0.015)$ & $(0.015)$ & $(0.027)$ & & & \\
& & & & $0.171^{* * *}$ & $0.175^{* * *}$ & $0.062^{* *}$ \\
$\ln$ (Electorate) & & & & $(0.023)$ & $(0.030)$ & $(0.028)$ \\
& & $-0.029^{* * *}$ & $-0.022^{*}$ & & $-0.033^{* * *}$ & $-0.022^{* *}$ \\
& & $(0.010)$ & $(0.011)$ & & $(0.010)$ & $(0.011)$ \\
Observations & & & & & & \\
Region FE & 340 & 338 & 338 & 322 & 320 & 320 \\
Year FE & YES & YES & YES & YES & YES & YES \\
Additional controls & YES & YES & YES & YES & YES & YES \\
$R^{2}$ & NO & NO & YES & NO & NO & YES \\
\hline \hline
\end{tabular}

Notes: This table presents the results of OLS estimates of the difference-in-differences effect of civicness on voting turnout, before and after the enfranchisement of 1912. The unit of analysis are region-election observations for 18 Italian regions over 19 national elections during the period 1861-1921 (2 regions did not vote in the first election in 1861). The dependent variable is the fraction of people that voted in each region-election. The explanatory variables of main interest are the interaction between the indicator variable Post, which is equal to 1 for all elections held after the enfranchisement and 0 otherwise, and two alternative measures of civicness: an indicator variable for regions in the north, which were not under the control of Bourbons before 1861, and the number of voluntarily associations per 10,000 inhabitants in 1885 (this last measure is not available for 1 region in the sample). The control variable $\ln$ (Electorate) is the lognumber of people in the electorate in each election-region. All regressions include region and election fixed effects; the bottom part of the table indicates whether the additional controls in Table 4 are also included (interactions of Post with literacy rates, firms over total population, workers in industry over total population and per-capita energy consumption). Robust standard errors are reported in parenthesis; $*{ }^{* *}$ and ${ }^{* * *}$ denote coefficients significantly different from zero at the $90 \%, 95 \%$ and $99 \%$ confidence level, respectively.

Table 6: share of non-elites and change in turnout around the enfranchisement, across electoral districts
(1)
(2)
(3)
(4)
(5)

(6)

\section{A. Ordinary least squares regression}

Non-elites

North x Non-elites

Associations x Non-elites

Constant

$\mathrm{R}^{2}$

Constant

\begin{tabular}{cc}
\multicolumn{2}{c}{ All regions } \\
\hline$-0.364^{* * *}$ & $-0.286^{* * *}$ \\
$(0.048)$ & $(0.078)$
\end{tabular}

$\begin{array}{lc}-0.364^{* * *} & -0.286^{* * *} \\ (0.048) & (0.078)\end{array}$

$0.176^{* * *}$

(0.033)

$0.139^{* * *}$

(0.041)

0.103

0.161

\begin{tabular}{cc} 
North & South \\
\hline$-0.185^{* *}$ & $-0.821^{* * *}$ \\
$(0.079)$ & $(0.118)$
\end{tabular}

\begin{tabular}{cc}
\multicolumn{2}{c}{ All regions } \\
\hline$-0.821^{* * *}$ & $-0.611^{* * *}$ \\
$(0.117)$ & $(0.181)$ \\
$0.006^{* * *}$ &
\end{tabular}

$(0.001)$

$\begin{array}{cccc}0.089^{* *} & 0.483^{* * *} & 0.089^{* *} & 0.047 \\ (0.041) & (0.089) & (0.041) & (0.058)\end{array}$

$0.109 \quad 0.248$

0.181

0.163 


\section{B. Weighted least squares regression}

Non-elites

North x Non-elites

Associations x Non-elites

Constant

$\mathrm{R}^{2}$

Non-elites

North x Non-elites

Associations x Non-elites

Constant

Observations

Region FE (region-specific shocks)

$\mathrm{R}^{2}$

$\begin{array}{cc}-0.205^{* *} & -0.813^{* * *} \\ (0.085) & (0.132)\end{array}$

$-0.813^{*}$

$(0.132)$

$0.006^{* * *}$

(0.002)
(0.081)

\begin{tabular}{cc}
$0.173^{* * *}$ & $0.138^{* * *}$ \\
$(0.035)$ & $(0.043)$ \\
0.097 & 0.155 \\
& C. Hu \\
\hline$-0.369^{* * *}$ & $-0.296^{* * *}$ \\
$(0.046)$ & $(0.067)$
\end{tabular}

\begin{tabular}{cccc} 
& & & $\begin{array}{c}0.003^{*} \\
(0.002)\end{array}$ \\
$0.095^{* *}$ & $0.476^{* * *}$ & $0.095^{* *}$ & 0.049 \\
$(0.044)$ & $(0.099)$ & $(0.044)$ & $(0.060)$ \\
& & & \\
0.108 & 0.225 & 0.171 & 0.156 \\
& & \\
\hline$-0.207^{* *}$ & $-0.804^{* * *}$ & $-0.806^{* * *}$ & $-0.624^{* * *}$ \\
$(0.081)$ & $(0.141)$ & $(0.168)$ & $(0.163)$ \\
& & $0.006^{* * *}$ &
\end{tabular}

$(0.002)$

$0.178^{* * *} \quad 0.136^{* * *}$

$0.093^{* *}$

$0.478^{* * *}$

0.051

(0.031)

$(0.037)$

$(0.044)$

(0.109)

$0.094^{* *}$

(0.064)

(0.039)

\begin{tabular}{cccccc}
496 & 496 & 312 & 184 & 496 & 487 \\
& & & & & \\
NO & YES & YES & YES & YES & YES \\
0.115 & 0.178 & 0.131 & 0.230 & 0.198 & 0.174 \\
\hline
\end{tabular}

Notes: This table presents estimates of the relationship between the share of non-elite voters and the change in voting turnout before and after Italy's 1912 enfranchisement across electoral districts, distinguishing between Northern and Southern regions. Dependent variable: change in voting turnout between the last pre-enfranchisement and the first post-enfranchisement election (years 1909 and 1913, respectively). Main explanatory variable: share of non-elite voters in each electoral district, estimated by the change in the electorate between the two elections over the total electorate in 1913, and its interaction with two alternative measures of civicness: an indicator for Northern regions that were not under the control of the Bourbons before 1861, and the number of voluntarily associations per 10,000 inhabitants in 1885 (this last measure is not available for 1 region in the sample). Panel A: OLS estimates; Panel B: weighed least squares, weights are the size of electoral districts in 1913: Panel C: Huber-White robust estimates. The bottom part of table indicates whether the regression includes in addition a linear trend or region and election fixed effects. Robust standard errors are reported in parenthesis; ${ }^{*}, *$ and ${ }^{* * *}$ denote coefficients significance at the $90 \%, 95 \%$ and $99 \%$ confidence level, respectively. 
Table 7: electoral support to socialist and communist parties in northern and southern regions, before and after the enfranchisement

\begin{tabular}{lccccc}
\hline \hline & $(1)$ & $(2)$ & $(3)$ & $(4)$ & $(5)$ \\
\cline { 2 - 6 } Voting turnout & $0.436^{* * *}$ & $0.299^{* * *}$ & $0.296^{* * *}$ & $0.294^{* * *}$ & $0.294^{* * *}$ \\
& $(0.071)$ & $(0.080)$ & $(0.079)$ & $(0.079)$ & $(0.079)$ \\
Voting turnout x Post & & $0.631^{* * *}$ & $0.586^{* *}$ & $0.568^{* *}$ & $0.610^{* *}$ \\
& & $(0.234)$ & $(0.262)$ & $(0.249)$ & $(0.263)$ \\
Union density x Post & & & 0.305 & & -1.276 \\
& & & $(0.841)$ & & $(1.529)$ \\
Strikes x Post & & & & 0.813 & 2.716 \\
& & & & $(1.318)$ & $(2.304)$ \\
Observations & & & & & \\
Region FE & 340 & 340 & 340 & 340 & 340 \\
Year FE & YES & YES & YES & YES & YES \\
$\mathrm{R}^{2}$ & YES & YES & YES & YES & YES \\
\hline \hline
\end{tabular}

Notes: This table presents OLS estimates of the relationship between voting turnout and the electoral results of socialist and communist parties. The unit of analysis are region-election observations for 18 Italian regions over 19 national elections during the period 1861-1921 (2 regions did not vote in the first election in 1861). The dependent variable is the fraction of valid voted in favor of socialist and communist parties in each region-election. The main explanatory variable is the voting turnout in each region-election, possibly interacted with the indicator variable Post, which is equal to 1 for all elections held after the enfranchisement and 0 otherwise. Additional controls include interactions of Post with union density and participation into workers' strikes over total population; the source of these variables is the Italian census of 1911, the detailed description is reported in the Appendix. The bottom part of the table indicates whether the regression includes in addition a linear trend or region and election fixed effects. Robust standard errors are reported in parenthesis; ${ }^{*},{ }^{* *}$ and ${ }^{* * *}$ denote coefficients significantly different from zero at the $90 \%, 95 \%$ and $99 \%$ confidence level, respectively. 
Table 8: list of referenda and nearest parliamentary election after WWII

\begin{tabular}{|c|c|c|}
\hline $\begin{array}{l}\text { Year of } \\
\text { referenda }\end{array}$ & $\begin{array}{l}\text { Nearest parliamentary } \\
\text { elections }\end{array}$ & Topic of referenda \\
\hline 1974 & 1972 & Divorce \\
\hline 1978 & 1979 & $\begin{array}{l}\text { Public funding to political parties, public order and } \\
\text { safety }\end{array}$ \\
\hline 1978 & 1979 & $\begin{array}{l}\text { Public funding to political parties, public order and } \\
\text { safety }\end{array}$ \\
\hline 1981 & 1979 & $\begin{array}{l}\text { Abortion, public order and safety, life sentence and } \\
\text { gun law }\end{array}$ \\
\hline 1985 & 1983 & Wage indexation \\
\hline 1987 & 1987 & $\begin{array}{l}\text { Liability of judges, nuclear power and financing of } \\
\text { local authorities }\end{array}$ \\
\hline 1989 & 1987 & Legislative mandate to the European parliament \\
\hline 1991 & 1992 & Electoral reform \\
\hline 1993 & 1992 & $\begin{array}{l}10 \text { proposals on public health, electoral reform and } \\
\text { organization of Ministries }\end{array}$ \\
\hline 1995 & 1994 & $\begin{array}{l}12 \text { proposals on the reform of labor relations, public } \\
\text { television and electoral law for local elections }\end{array}$ \\
\hline
\end{tabular}

Notes: This table shows the list of referenda and nearest parliamentary elections that we use in to compute differences in turnout across regions, as shown in Figure 6. We exclude the constitutional referenda in 1946 as participation was strongly affected by difference in preferences between monarchy and republic between the South and the North and all the referenda that took place after 1995 as many did not reach the quorum. 